This item was submitted to Loughborough's Research Repository by the author.

Items in Figshare are protected by copyright, with all rights reserved, unless otherwise indicated.

\title{
Vanadium(V) oxo and Imido calix[8]arene complexes: synthesis, structural studies, and ethylene homo/copolymerisation capability
}

\section{PLEASE CITE THE PUBLISHED VERSION}

http://dx.doi.org/10.1002/chem.201406084

\section{PUBLISHER}

(C) Wiley-VCH Verlag GmbH \& Co.

\section{VERSION}

AM (Accepted Manuscript)

\section{PUBLISHER STATEMENT}

This work is made available according to the conditions of the Creative Commons Attribution-NonCommercialNoDerivatives 4.0 International (CC BY-NC-ND 4.0) licence. Full details of this licence are available at: https://creativecommons.org/licenses/by-nc-nd/4.0/

\section{LICENCE}

CC BY-NC-ND 4.0

\section{REPOSITORY RECORD}

Redshaw, Carl, Mark J. Walton, Darren S. Lee, Chengying Jiang, Mark R.J. Elsegood, and Kenji Michiue. 2019. "Vanadium(v) Oxo and Imido Calix[8]arene Complexes: Synthesis, Structural Studies, and Ethylene Homo/copolymerisation Capability". figshare. https://hdl.handle.net/2134/18062. 


\section{Vanadium(V) Oxo and Imido calix[8]arene complexes: Synthesis, structural studies and ethylene homo-(co-)polymerization capability.}

Carl Redshaw, ${ }^{\mathrm{a}, *}$ Mark J. Walton, ${ }^{\mathrm{b}}$ Darren S. Lee, ${ }^{\mathrm{c}}$ Chengying Jiang, ${ }^{\mathrm{c}}$ and Mark R.J. Elsegood ${ }^{\mathrm{c}}$ and Kenji Michiue $^{\mathrm{d}}$

${ }^{a}$ Department of Chemistry, University of Hull, Hull, HU6 7RX, U.K.

$b$

Energy Materials Laboratory, School of Chemistry, University of East Anglia, Norwich, NR4 7TJ, $U . K$.

${ }^{c}$ Chemistry Department, Loughborough University, Loughborough, Leicestershire, LE11 3TU,U.K.

${ }^{d}$ Process Technology Center, Mitsui Chemicals Inc., 580-32 Nagaura, Sodegaura, Chiba 299-0265, Japan

Abstract: Interaction of p-tert-butylcalix[8]areneH $\mathrm{H}_{8}\left(\mathrm{~L}^{8} \mathrm{H}_{8}\right)$ with in-situ generated $\left[\mathrm{NaVO}(\mathrm{O} \text { - } \mathrm{Bu})_{4}\right]($ from $\mathrm{VOCl}_{3}$ and four equivalents of $\left.\mathrm{NaO} t \mathrm{Bu}\right)$ afforded the dark brown complex $\left[\mathrm{Na}(\mathrm{NCMe})_{5}\right]\left[(\mathrm{VO})_{2} \mathrm{~L}^{8} \mathrm{H}\right] \cdot 4 \mathrm{MeCN}(\mathbf{1} \cdot 4 \mathrm{MeCN})$, in which the calix[8]arene adopts a saddle-shaped conformation. Increasing (to four equivalents per $\mathrm{L}^{8}$ ) the amount of $\left[\mathrm{NaVO}(\mathrm{O} t \text {-Bu })_{4}\right]$ present in the reaction, led to the formation of the yellow octa-vanadyl complex $\left\{\left[\left(\mathrm{Na}(\mathrm{VO})_{4} \mathrm{~L}^{8}\right)(\mathrm{Na}(\mathrm{NCMe}))_{3}\right]\right.$ $\left[\mathrm{Na}(\mathrm{NCMe})_{6}\right\}_{2} \cdot 10 \mathrm{MeCN}(\mathbf{2} \cdot 10 \mathrm{MeCN})$, in which the calix[8]arene adopts a pleated loop conformation. In the presence of adventitious oxygen, reaction of four equivalents of $\left[\mathrm{VO}(\mathrm{O} t-\mathrm{Bu})_{3}\right]$ (generated from $\mathrm{VOCl}_{3}$ and $3 \mathrm{KO} t \mathrm{Bu})$ with $\mathrm{L}^{8} \mathrm{H}_{8}$ afforded the alkali-metal free green complex $\left[(\mathrm{VO})_{4} \mathrm{~L}^{8}\left(\mu^{3}-\mathrm{O}\right)_{2}\right](3)$; the solvates 3.3 MeCN and $3 \cdot 3 \mathrm{CH}_{2} \mathrm{Cl}_{2}$ have been isolated. In both solvates, the $\mathrm{L}^{8}$ ligand adopts a shallow saddle-shaped conformation, supporting a core comprising of a $(\mathrm{VO}){ }_{4} \mathrm{O}_{4}$ ladder. In the case of lithium, in order to obtain crystalline material, it was found necessary to reverse the order of addition such that lithium tert-butoxide 
was added to $\mathrm{L}^{8} \mathrm{H}_{8}$, and then subsequently treated (at $-78{ }^{\circ} \mathrm{C}$ ) with two equivalents of $\mathrm{VOCl}_{3}$; crystallization from tetrahydrofuran (THF) afforded $\left\{\left(\mathrm{VO}_{2}\right)_{2} \mathrm{Li}_{6}\left[\mathrm{~L}^{8}\right](\operatorname{thf})_{2}(\mathrm{OtBu})_{2}\left(\mathrm{Et}_{2} \mathrm{O}\right)_{2}\right\} \cdot \mathrm{Et}_{2} \mathrm{O}\left(4 \cdot \mathrm{Et}_{2} \mathrm{O}\right)$. In the structure of $4 \cdot \mathrm{Et}_{2} \mathrm{O}$, vanadium, lithium and oxygen form a central lattern-type cage, which is capped top and bottom by an $\mathrm{Li}_{2} \mathrm{O}_{2}$ diamond; the calix[8]arene is in a 'down, down, out, out, down, down' conformation. When the 'same reaction' was extracted into acetonitrile $(\mathrm{MeCN})$, the salt complex $\left[\mathrm{Li}(\mathrm{NCMe})_{4}\right]\left[(\mathrm{VO})_{2}{ }^{2}{ }^{8} \mathrm{H}\right] \cdot 8 \mathrm{MeCN}(\mathbf{5} \cdot \mathrm{MeCN})$ was formed. In $\mathbf{5} \cdot 8 \mathrm{MeCN}$, the $\left[\mathrm{Li}(\mathrm{NCMe})_{4}\right]$ cations reside between the anions in the clefts of $\mathrm{L}^{8} \mathrm{H}$, the latter adopting a saddle-shaped conformation. Use of the imido precursors $\left[\mathrm{V}(\mathrm{N} t-\mathrm{Bu})(\mathrm{O} t-\mathrm{Bu})_{3}\right]$ and $\left[\mathrm{V}(\mathrm{N} p\right.$-tolyl $\left.)(\mathrm{O} t-\mathrm{Bu})_{3}\right]$ and $\mathrm{L}^{8} \mathrm{H}_{8}$, afforded, via an imido exchange, the salt $\left[t-\mathrm{BuNH}_{3}\right]\left\{[\mathrm{V}(p \text {-tolylN })]_{2} \mathrm{~L}^{8} \mathrm{H}\right\} \cdot 3^{1 / 2} \mathrm{MeCN}\left(\mathbf{6} \cdot 3^{1} \frac{1}{2} \mathrm{MeCN}\right)$. The molecular structures of $\mathbf{1}$ to $\mathbf{6}$ are reported; data collections for complexes $2 \cdot 10 \mathrm{MeCN}, 3 \cdot 3 \mathrm{MeCN}$ and $3 \cdot 3 \mathrm{CH}_{2} \mathrm{Cl}_{2}$ required the use of synchrotron radiation. Complexes 1, $\mathbf{3}$ and $\mathbf{4}$ have been screened as pre-catalysts for the polymerization of ethylene in the presence of a variety of co-catalysts (with and without a re-activator) at various tempertures and for the co-polymerization of ethylene with propylene; results are compared versus the benchmark catalyst $\mathrm{VO}(\mathrm{OEt}) \mathrm{Cl}_{2}$. In some cases, activities as high as $136,000 \mathrm{~g} / \mathrm{mmol}$.v.h were achievable, whilst it also proved possible to obtain higher molecular weight polymers (in comparible yields) versus the use of $\mathrm{VO}(\mathrm{OEt}) \mathrm{Cl}_{2}$. In the case of the co-polymerization, the incorporation of propylene was $7.1-10.9 \mathrm{~mol} \%$ (cf $10 \mathrm{~mol} \%$ for $\left.\mathrm{VO}(\mathrm{OEt}) \mathrm{Cl}_{2}\right)$, though catalytic activities were lower versus $\mathrm{VO}(\mathrm{OEt}) \mathrm{Cl}_{2}$.

Keywords: Vanadium; calix[8]arene; ethylene polymerization; ethylene/propylene co-polymerization; crystal structures. 


\section{Introduction}

The use of calix $[n]$ arenes in a variety of catalytic/polymerization processes continues to attract interest.

[1] However, the majority of the work in the literature has focussed on systems employing the 'simplest' of the calixarene family, p-tert-butylcalix[4]areneH $\mathrm{H}_{4}$, partly due to its ease of preparation (low cost), but also given the calix[4]arene ligand set tends to bind to only one metal, retaining a cone conformation, thereby making characterization relatively simple. Furthermore, Floriani recognized that the calix[4]arene ligand system, with the four oxygen donors of the lower-rim, was pre-organized in a quasi-planar geometry, and offered an ideal opportunity for modelling an oxo surface and thereby heterogeneous catalysts. [2] By contrast, the coordination chemistry associated with the larger calix $[n]$ arenes $(n>4)$ is less well studied, [3, 4] presumably reflecting the often increased costs associated with the preparation of these larger ligands, as well as the more complicated characterization necessary for resulting larger metallocalix $[n]$ arenes. However, there are advantages for targeting larger metallocalix $[n]$ arenes, for example their increased conformational flexibility, presence of multiple cavities and their ability to coordinate simultaneously multiple metal centres, means that such systems are becoming of increased structural interest. With respect to catalysis, the ability to coordinate multiple metal centres in close proximity has the potential to lead to useful cooperative effects. [5] With this in mind, we now describe the synthesis and solid-state structures of a number of new vanadium(V) p-tert-butylcalix[8]arene complexes (chart 1), noting that structural reports of vanadium complexes of the larger calix $[n]$ arenes remain scant. $[3,6,7]$ In the case of vanadium-based calixarene catalysis, Limberg et al have screened such systems for the oxidative dehydrogenation of short chain alkanes and alcohols, [6] whilst our group has screened a range of vanadyl-containing calix $[n]$ arenes for $\alpha$-olefin homo-(co-)polymerization. [7] We have also described the difficulties associated with the use of alkali metal alkoxides, and the resulting structural complications for a 
number of chromium(III) and iron(III) complexes bearing p-tert-butylcalix[4 and 6]arenes. [8, 9] Herein, similar use of alkali metal alkoxides also leads to some intriguing p-tert-butylcalix[8]arene structures, and, given the current interest in the potential of vanadium-based systems for olefin polymerization, a number of the vanadyl complexes prepared herein have been screened for their ability to polymerize ethylene and co-polymerize ethylene with propylene. The use of different cocatalysts is evaluated as is the variation of temperature on the catalytic performance; results are compared versus the benchmark catalyst $\mathrm{VO}(\mathrm{OEt}) \mathrm{Cl}_{2}$. We note that our recent studies using vanadyl ptert-butylcalix[6]arene complexes revealed that activities as high as 202,500 $\mathrm{g} / \mathrm{mmol}$.v.h were achievable, although such systems suffered somewhat from thermal instability. [10]
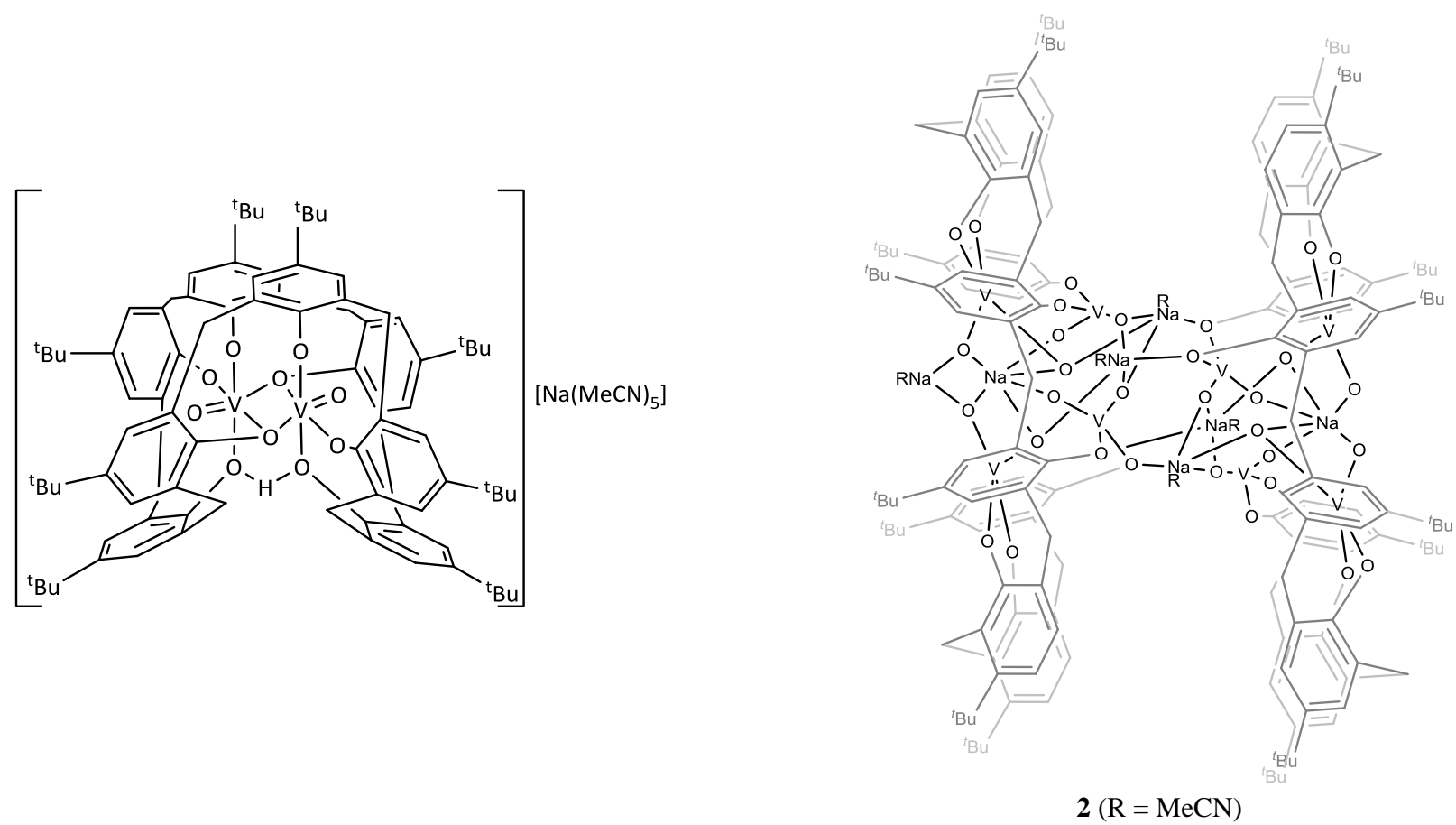


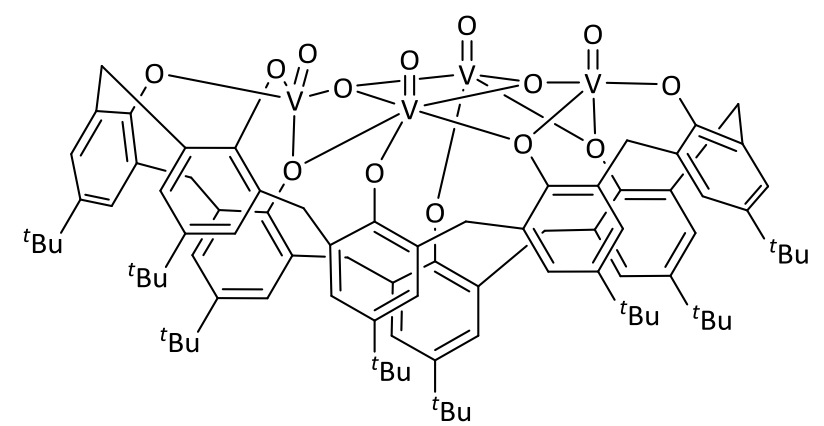

3

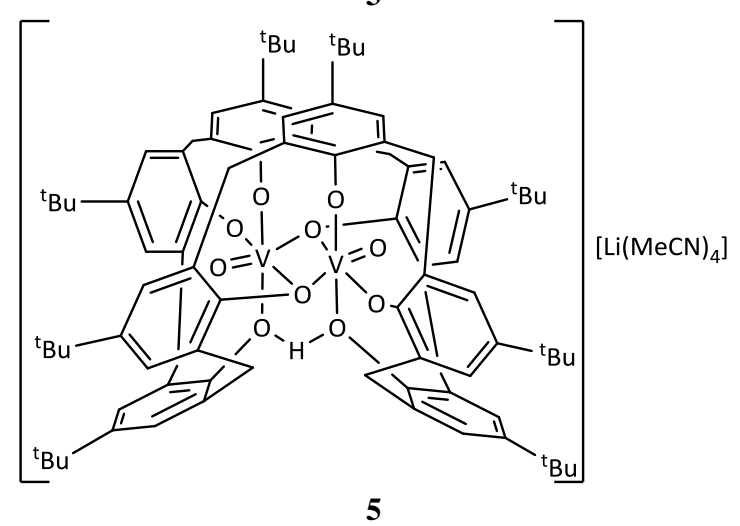

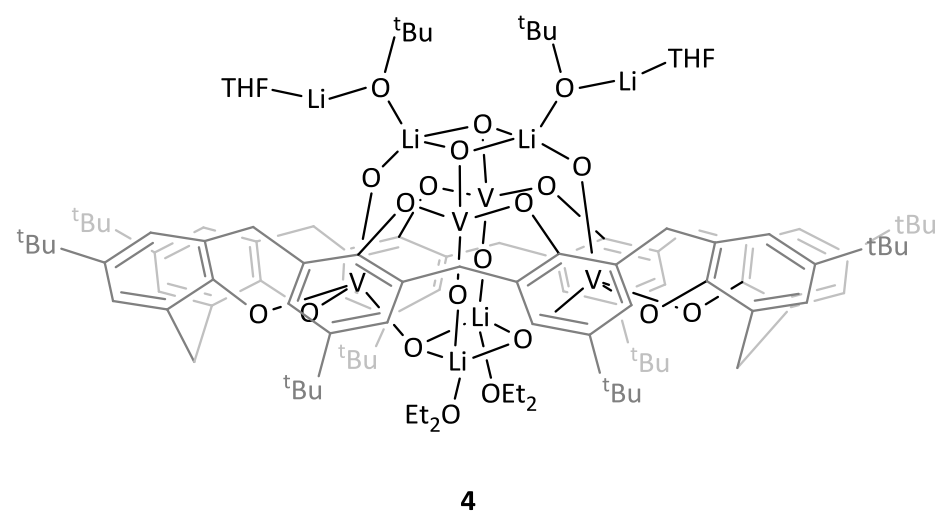

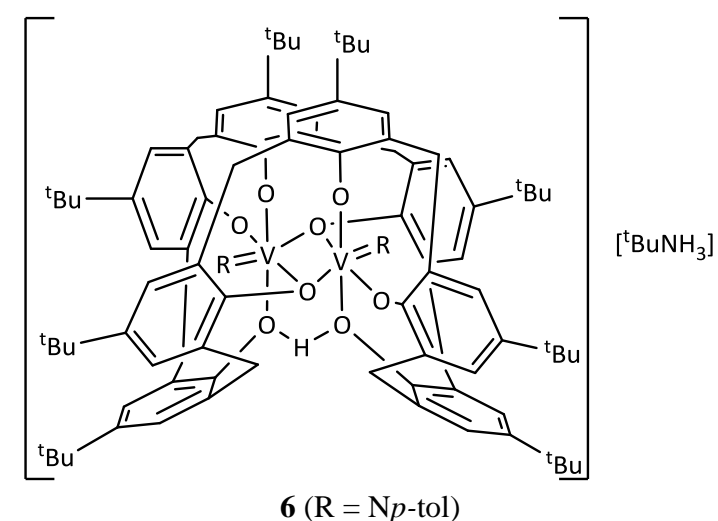

Chart 1. Vanadium calix[8]arenes prepared in this work.

\section{Results and Discussion}

'Vanadyl sodium' complexes

Interaction of p-tert-butylcalix[8]arene $\mathrm{H}_{8}\left(\mathrm{~L}^{8} \mathrm{H}_{8}\right)$ with $\left[\mathrm{NaVO}(\mathrm{O} t-\mathrm{Bu})_{4}\right]$ (prepared in-situ from $\mathrm{VOCl}_{3}$ and excess $\mathrm{NaO} t \mathrm{Bu}$ using a modification of the method of Wilkinson [11]) afforded the dark brown complex $\left[\mathrm{Na}(\mathrm{NCMe})_{5}\right]\left[(\mathrm{VO})_{2} \mathrm{~L}^{8} \mathrm{H}\right] \cdot 5 \mathrm{MeCN} \cdot(\mathbf{1} 4 \mathrm{MeCN})$, in $c a .47 \%$ yield. Crystals of $\mathbf{1} \cdot 4 \mathrm{MeCN}$ suitable for single crystal X-ray diffraction studies were grown from saturated acetonitrile solutions after prolonged standing at ambient temperature. The molecular structure of complex $\mathbf{1}$ is presented in Figure 1; crystallographic data are collated in Table 6. The structure of this salt is similar to those previously reported by Pedersen et al and by Limberg et al, who prepared ammonium and phosphonium salts, respectively. [6, 12] As shown in Figure 2, the calix[8]arene adopts a saddle- 
shaped conformation, which creates two small cavities, each comprising three phenolic groups, at each 'end' of the complex. One oxygen $[\mathrm{O}(5)]$ remains protonated and forms a hydrogen bond with $\mathrm{O}(1)$. The geometry at each vanadium centre is best described as pseudo octahedral, and these vanadium centres are linked via asymmetric aryloxide bridges, with the longer bridging bond lying trans to the oxo function. Selected structural parameters for $\mathbf{1}$ and those of the 'Limberg structure' (CCDC 610228) are compared in Table 1; the 'Pedersen structure' was not characterized crystallographically (rather it was inferred by NMR spectroscopic data and by comparison with a crystallographically characterized titanium complex of $\left.\mathrm{L}^{8} \mathrm{H}\right)$. As expected, there is good agreement between the geometrical parameters for each structure, for example terminal $\mathrm{V}=\mathrm{O}$ bonds lengths 1.589(2) and 1.591(2) $\AA$ in 1 compare favourably with those reported by Limberg [1.589(2) and 1.599(2) $\AA$ ]. The sodium cation in 1 is bound by five acetonitrile molecules.

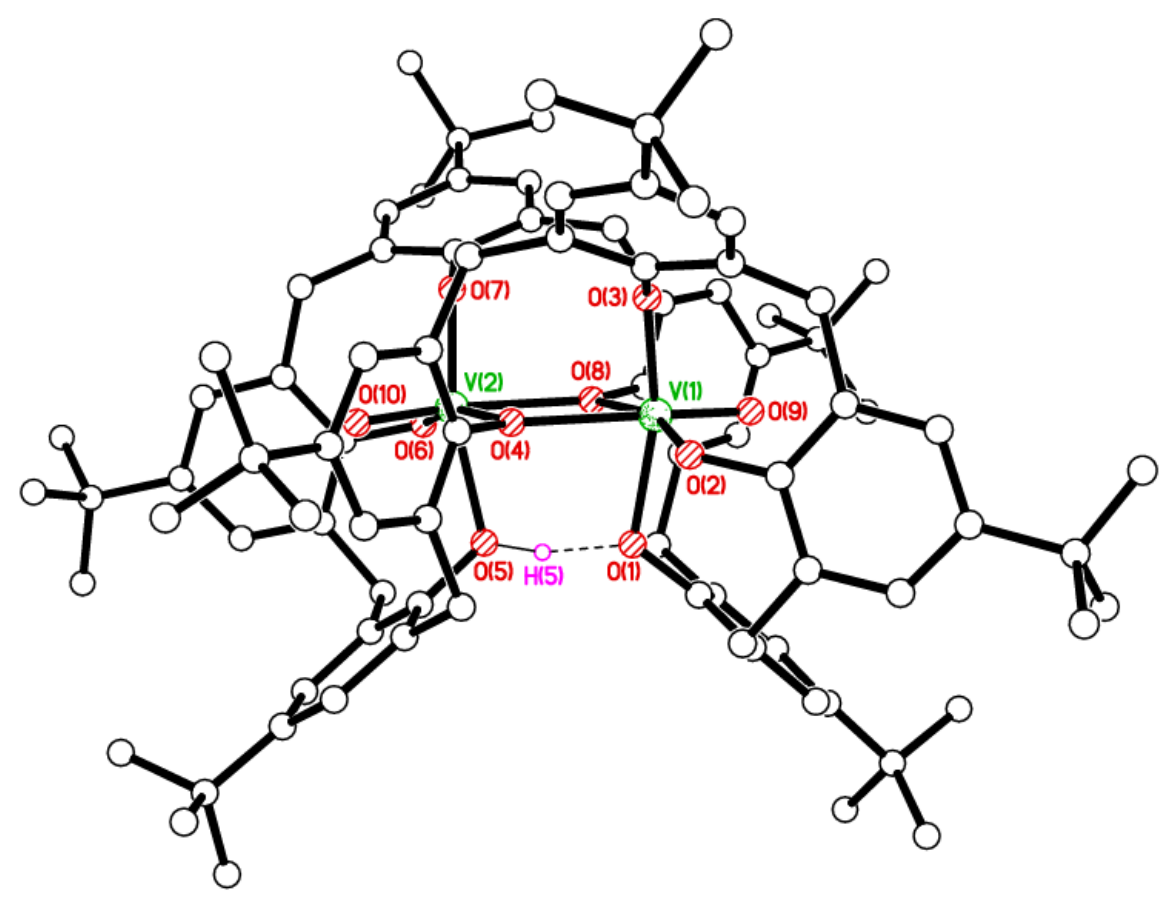




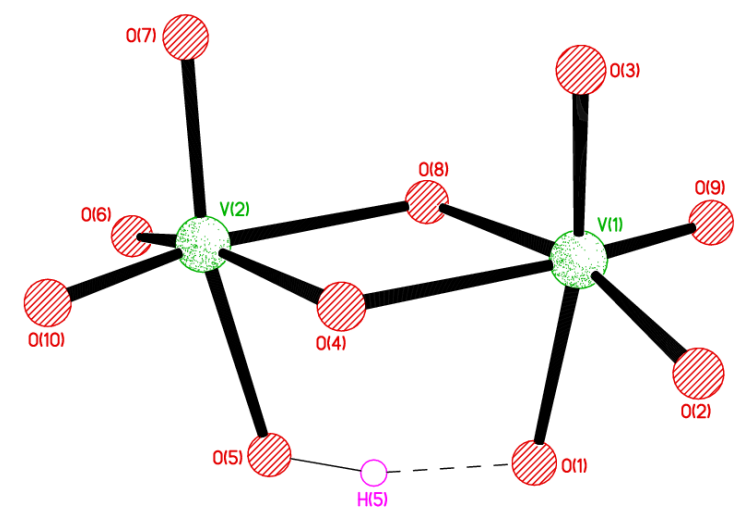

Figure 1. Top: view of $\mathbf{1}$ showing the atom numbering scheme and revealing the saddle-shaped geometry of $\mathrm{L}^{8} \mathrm{H}$. H atoms except $\mathrm{H}(5)$, the $\left[\mathrm{Na}(\mathrm{NCMe})_{5}\right]^{+}$cation, and five MeCN molecules of crystallisation are omitted for clarity. Below: the core of $\mathbf{1}$.

Table 1. Selected structural data for 1 and Limberg salt $\left[\mathrm{PPh}_{4}\right]\left[(\mathrm{VO})_{2} \mathrm{~L}^{8} \mathrm{H}\right]$

\begin{tabular}{ccc}
\hline Bond length $(\AA) /$ Angle $\left({ }^{\circ}\right)$ & $\mathbf{1}$ & Limberg salt \\
\hline $\mathrm{V}(1)-\mathrm{O}(1)$ & $2.0148(19)$ & $2.036(2)$ \\
$\mathrm{V}(1)-\mathrm{O}(2)$ & $1.8452(19)$ & $1.849(2)$ \\
$\mathrm{V}(1)-\mathrm{O}(3)$ & $1.855(2)$ & $1.852(2)$ \\
$\mathrm{V}(1)-\mathrm{O}(4)$ & $2.181(2)$ & $2.212(2)$ \\
$\mathrm{V}(1)-\mathrm{O}(8)$ & $1.9916(19)$ & $1.992(2)$ \\
$\mathrm{V}(1)-\mathrm{O}(9)$ & $1.589(2)$ & $1.589(2)$ \\
$\mathrm{V}(1) \cdots \mathrm{V}(2)^{\mathrm{a}}$ & $3.3695(7)$ & $3.3677(7)$ \\
& & \\
$\mathrm{O}(1)-\mathrm{V}(1)-\mathrm{O}(3)$ & $163.56(9)$ & $162.87(8)$ \\
$\mathrm{O}(4)-\mathrm{V}(1)-\mathrm{O}(8)$ & $72.11(7)$ & $71.89(6)$ \\
$\mathrm{O}(4)-\mathrm{V}(1)-\mathrm{O}(9)$ & $165.81(9)$ & $164.44(8)$ \\
$\mathrm{V}(1)-\mathrm{O}(4)-\mathrm{V}(2)$ & $108.33(9)$ & $107.20(8)$ \\
$\mathrm{V}(1)-\mathrm{O}(8)-\mathrm{V}(2)$ & $107.28(8)$ & $107.77(8)$
\end{tabular}

${ }^{\mathrm{a}}$ Not bonded.

Increasing the amount of $\left[\mathrm{NaVO}(\mathrm{O} t-\mathrm{Bu})_{4}\right]$ present in the reaction to four equivalents, led to the formation of $\left\{\left[\left(\mathrm{Na}(\mathrm{VO})_{4} \mathrm{~L}^{8}\right)(\mathrm{Na}(\mathrm{NCMe}))_{3}\right]\left[\mathrm{Na}(\mathrm{NCMe})_{6}\right]\right\}_{2} \cdot 10 \mathrm{MeCN}(2 \cdot 10 \mathrm{MeCN})$. Small crystals of 
2 $10 \mathrm{MeCN}$ suitable for single crystal X-ray diffraction studies using synchrotron radiation were grown from saturated acetonitrile solutions after prolonged standing at $-25^{\circ} \mathrm{C}$. A view of the molecular structure of compound $\mathbf{2}$ is presented in Figures 2, together with a picture of the core; selected bond lengths and angles are given in the caption.
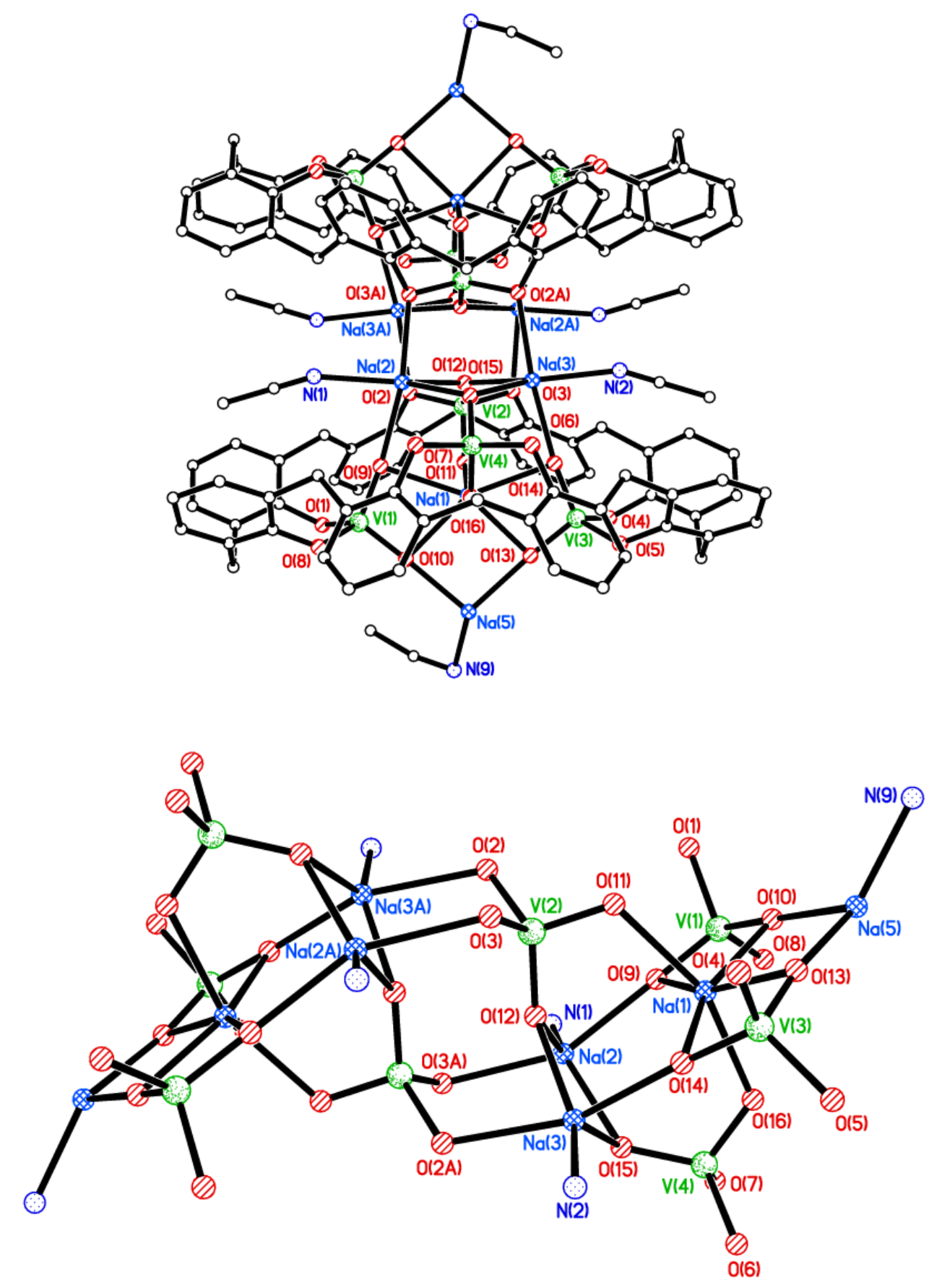
Figure 2. Top: view of the anion in 2. Hydrogen atoms, tert-butyl groups on the calixarene and noncoordinated solvent molecules have been omitted for clarity. Note: $\mathrm{Na}(5)$ and the attached $\mathrm{MeCN}$ are $50 \%$ occupied, i.e. on average, only one of these groups per anion. Below: the core of 2 . Selected bond lengths $(\AA)$ and angles $\left({ }^{\circ}\right)$ : V(1) - O(1) 1.810(5), V(1) - O(8) 1.824(5), V(1) - O(9) 1.646(5), V(1) $\mathrm{O}(10)$ 1.630(5), $\mathrm{V}(2)-\mathrm{O}(2) 1.846(4), \mathrm{V}(2)-\mathrm{O}(3) 1.841(4), \mathrm{V}(2)-\mathrm{O}(11) 1.597(5), \mathrm{V}(2)-\mathrm{O}(12)$ 1.670(4), V(3) - O(4) 1.802(5), V(3) - O(5) 1.813(5), V(3) - O(13) 1.619(5), V(3) - O(14) 1.646(4), $\mathrm{V}(4)-\mathrm{O}(6) 1.826(5), \mathrm{V}(4)-\mathrm{O}(7) 1.818(5), \mathrm{V}(4)-\mathrm{O}(15)$ 1.649(4), Na - O range 2.24-2.51(2); $\mathrm{O}(1)-$ $\mathrm{V}(1)-\mathrm{O}(8)$ 105.4(2), $\mathrm{O}(1)-\mathrm{V}(1)-\mathrm{O}(9)$ 112.7(2), $\mathrm{O}(8)-\mathrm{V}(1)-\mathrm{O}(9) 113.2(2), \mathrm{O}(2)-\mathrm{V}(2)-\mathrm{O}(3)$ 106.21(18), $\mathrm{O}(2)-\mathrm{V}(2)-\mathrm{O}(12)$ 116.2(2), $\mathrm{O}(4)-\mathrm{V}(3)-\mathrm{O}(5)$ 105.1(2), $\mathrm{O}(4)-\mathrm{V}(3)-\mathrm{O}(14) 112.4(2)$ $\mathrm{O}(6)-\mathrm{V}(4)-\mathrm{O}(7) 106.8(2), \mathrm{O}(6)-\mathrm{V}(4)-\mathrm{O}(15) 111.6(2)$

The molecule is located on an inversion centre, with each half containing four $\mathrm{VO}_{2}$ units, surrounding a six-coordinate sodium cation, $\mathrm{Na}(1)$. The two halves of the molecule are linked via a central $\mathrm{V}_{2} \mathrm{Na}_{2} \mathrm{O}_{4}$ unit. The $\mathrm{L}^{8}$ ligand forms a 'pleated-loop' conformation. Four sodium cations (two unique) reside within the framework connecting the two calixarenes and are each bound by one solvent molecule. At one end of the molecule or the other, but not both, is a further $\mathrm{Na}(\mathrm{NCMe})$ group, containing $\mathrm{Na}(5)$, highlighting the ability of such systems to pick up solvated alkali metals at any exposed oxygen sites. A further sodium per asymmetric unit is present, and this is bound by six acetonitriles, and acts as a separate cationic unit.

\section{'Vanadyl potassium' complexes}

By contrast, in the presence of adventitious oxygen, the use of four equivalents $\left[\mathrm{VO}(\mathrm{O} t-\mathrm{Bu})_{3}\right]$ (generated in-situ from $\left[\mathrm{VOCl}_{3}\right]$ and $3 \mathrm{KO} t \mathrm{Bu}$ ) and $\mathrm{L}^{8} \mathrm{H}_{8}$ afforded the alkali-metal free, green complex 
$\left[(\mathrm{VO})_{4} \mathrm{~L}^{8}\left(\mu^{3}-\mathrm{O}\right)_{2}\right](\mathbf{3})$. Two solvates, namely $\mathbf{3} \cdot 3 \mathrm{MeCN}$ and $\mathbf{3} \cdot 3 \mathrm{CH}_{2} \mathrm{Cl}_{2}$ have been isolated from workups involving either acetonitrile or dichloromethane, respectively, and structurally characterized. Diffraction data for both solvates of $\mathbf{3}$ were collected using synchrotron radiation. They are isomorphous and both are twinned (see experimental section).

Views of two solvates, $3 \cdot 3 \mathrm{MeCN}$ and $\mathbf{3} \cdot 3 \mathrm{CH}_{2} \mathrm{Cl}_{2}$ are presented in Figure 3. In both molecules, the geometry around each vanadium centre is very similar (square-pyramidal), reflected by the near identical bond lengths and angles - see Table 2. Each molecule lies on a centre of inversion.

Table 2. Selected structural data for the solvates $3 \cdot 3 \mathrm{MeCN}$ and $\mathbf{3} \cdot 3 \mathrm{CH}_{2} \mathrm{Cl}_{2}$.

\begin{tabular}{ccc}
\hline Bond lengths $(\AA) /$ Angle $\left(^{\circ}\right)$ & $3 \cdot 3 \mathrm{MeCN}$ & $3 \cdot 3 \mathrm{CH}_{2} \mathrm{Cl}_{2}$ \\
\hline $\mathrm{V}(1)-\mathrm{O}(3)$ & $1.914(5)$ & $1.914(3)$ \\
$\mathrm{V}(1)-\mathrm{O}(4)$ & $1.776(6)$ & $1.762(3)$ \\
$\mathrm{V}(1)-\mathrm{O}(10)$ & $1.572(6)$ & $1.573(3)$ \\
$\mathrm{V}(1)-\mathrm{O}(13)$ & $1.946(6)$ & $1.939(3)$ \\
$\mathrm{V}(1)-\mathrm{O}(14)$ & $1.931(5)$ & $1.949(3)$ \\
$\mathrm{V}(3)-\mathrm{O}(1)$ & $1.799(6)$ & $1.798(3)$ \\
$\mathrm{V}(3)-\mathrm{O}(2)$ & $1.786(6)$ & $1.788(2)$ \\
$\mathrm{V}(3)-\mathrm{O}(3)$ & $2.214(6)$ & $2.200(3)$ \\
$\mathrm{V}(3)-\mathrm{O}(9)$ & $1.562(6)$ & $1.580(3)$ \\
$\mathrm{V}(3)-\mathrm{O}(13)$ & $1.878(5)$ & $1.884(3)$ \\
& & \\
$\mathrm{V}(1)-\mathrm{O}(3)-\mathrm{V}(3)$ & $98.7(2)$ & $97.56(12)$ \\
$\mathrm{V}(1)-\mathrm{O}(13)-\mathrm{V}(3)$ & $110.3(3)$ & $108.36(14)$ \\
$\mathrm{V}(1)-\mathrm{O}(13)-\mathrm{V}(2)$ & $103.2(2)$ & $104.62(13)$ \\
$\mathrm{V}(1)-\mathrm{O}(14)-\mathrm{V}(4)$ & $145.2(3)$ & $143.97(17)$
\end{tabular}

The two fully deprotonated calix[8]arene moieties each adopt a shallow, saddle-shaped conformation and chelate to four penta-coordinated vanadyl centres. The vanadium and oxygen atoms are arranged 
in a ladder-like configuration (Figure 3, top), similar to that reported for a number of titanium based calixarene complexes, for example $\mathbf{I}$ and more recently for the iron(III) calix[6]arene complex $\left[\left\{\mathrm{Fe}_{2}(\mu-\right.\right.$ $\left.\left.\mathrm{O}) \mathrm{L}^{6}\left(\mathrm{~K}(\mathrm{NCMe})_{2}\right)_{2}\right\}_{2}\right] \cdot 10.8 \mathrm{MeCN}$ II (see Chart 2), [9]

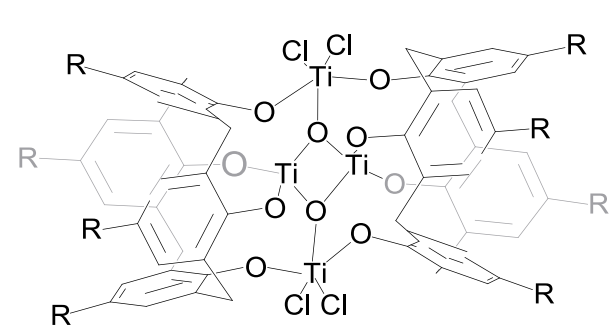

I

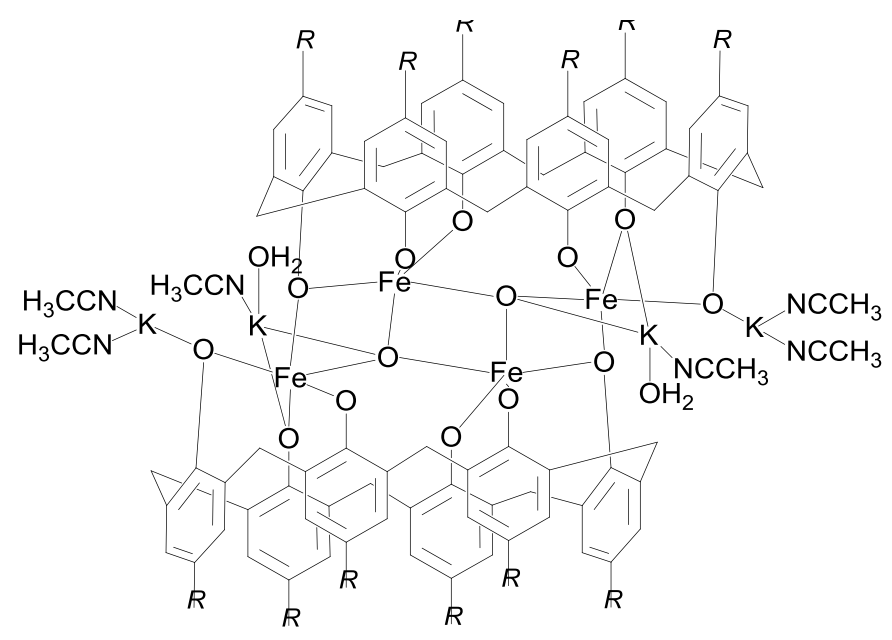

II

Chart 2

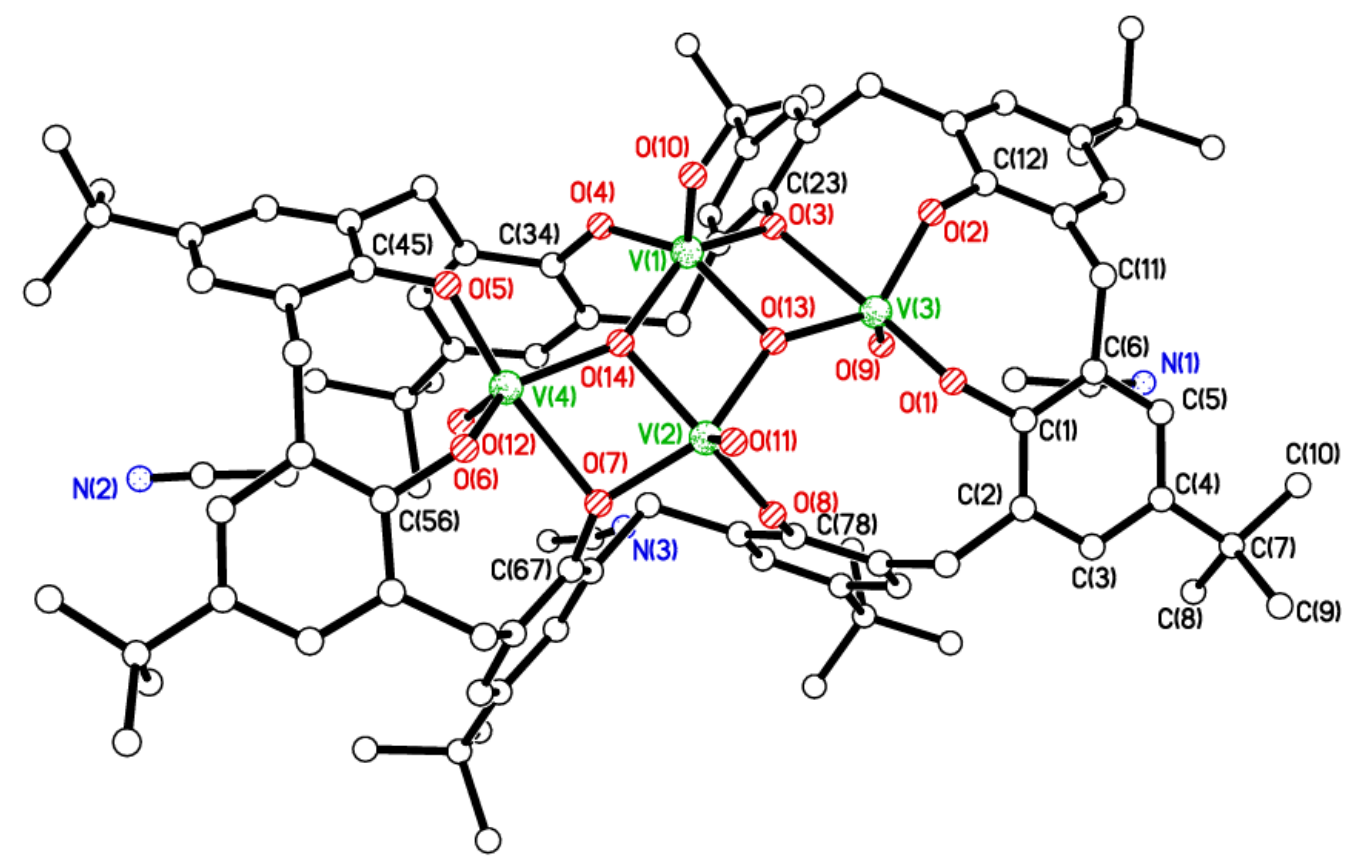




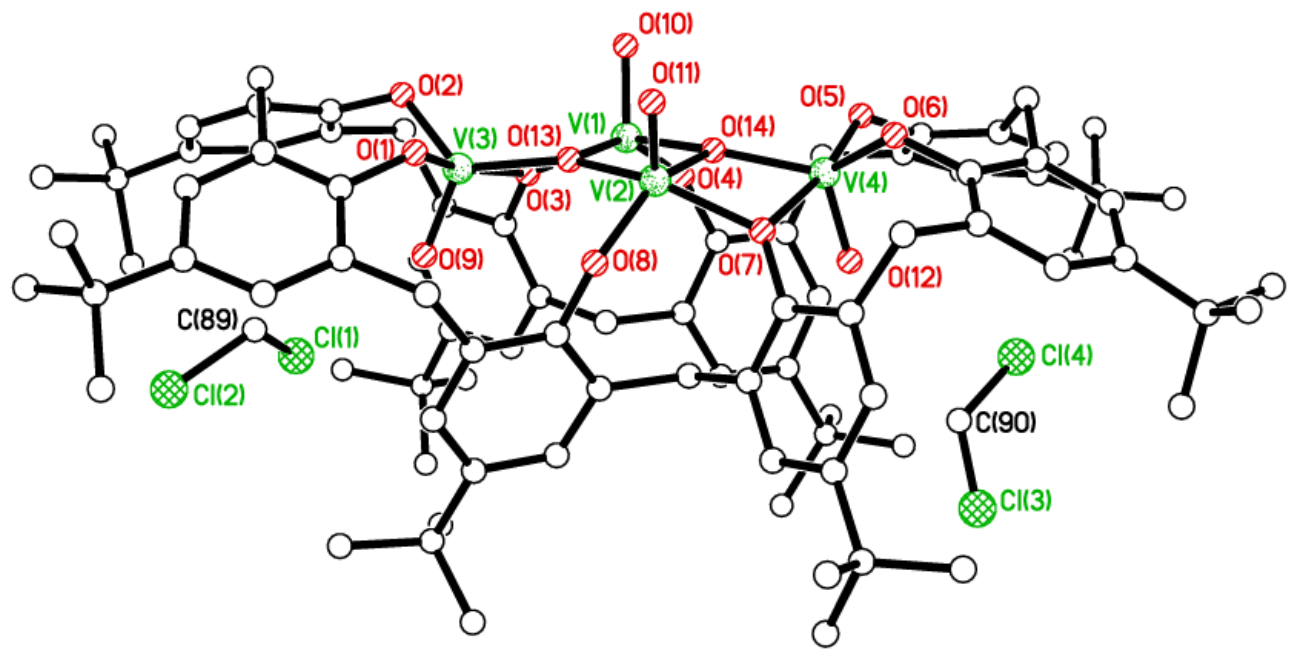

Figure 3-Views of the two solvates, $\mathbf{3} \cdot 3 \mathrm{MeCN}$ (top) and $\mathbf{3} \cdot 3 \mathrm{CH}_{2} \mathrm{Cl}_{2}$ (bottom). Hydrogen atoms have been omitted for clarity. Top: this view highlights the $\mathrm{V}_{4} \mathrm{O}_{4}$ ladder in the core; below: this view shows two of the three solvent molecules encapsulated by the calixarene, one at each end of the molecule.

\section{'Vanadyl lithium' complexes}

In the case of lithium, in order to obtain crystalline material, it was necessary to reverse the order of addition such that lithium tert-butoxide was added to $\mathrm{L}^{8} \mathrm{H}_{8}$, and subsequently treated (at $-78{ }^{\circ} \mathrm{C}$ ) with two equivalents of $\mathrm{VOCl}_{3}$; crystallization from tetrahydrofuran (THF) afforded $\left\{\left(\mathrm{VO}_{2}\right)_{2} \mathrm{Li}_{6}\left[\mathrm{~L}^{8}\right](\mathrm{thf})_{2}(\mathrm{OtBu})_{2}\left(\mathrm{Et}_{2} \mathrm{O}\right)_{2}\right\} \cdot \mathrm{Et}_{2} \mathrm{O} \quad\left(\mathbf{4} \cdot \mathrm{Et}_{2} \mathrm{O}\right)$. Two views of the molecular structure of compound 4 are presented in Figures $4 \mathrm{a}$ and 4b, together with a picture of the core (Figure 5); selected bond lengths and angles are given in the caption. 

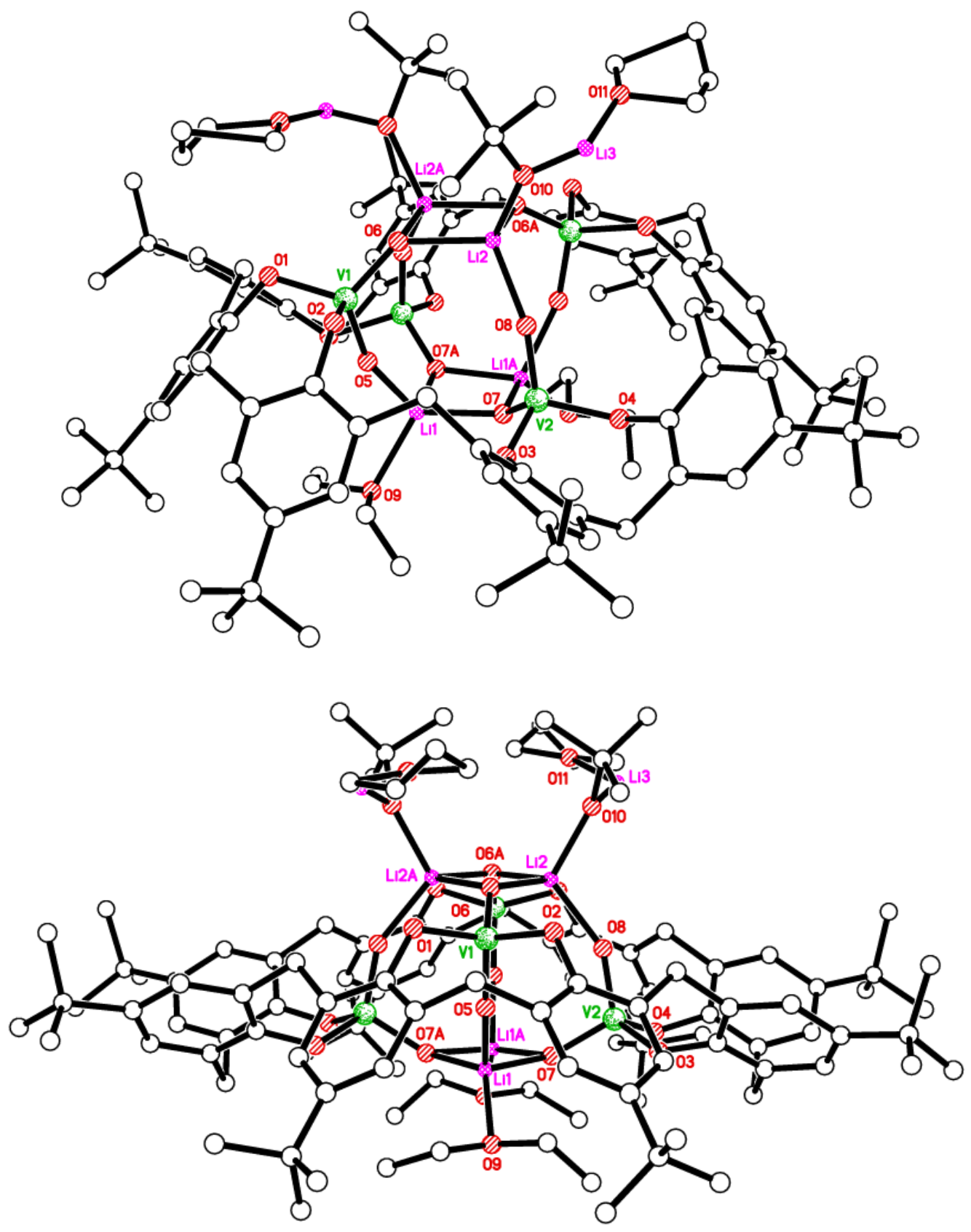

Figure 4. Two views of the complex $4 \cdot \mathrm{Et}_{2} \mathrm{O}$. Selected bond lengths $(\AA)$ and angles $\left(^{\circ}\right)$ : $\mathrm{V}(1)-\mathrm{O}(1)$ 1.825(3), $\mathrm{V}(1)-\mathrm{O}(2) 1.821(3), \mathrm{V}(1)-\mathrm{O}(5)$ 1.618(3), $\mathrm{V}(1)-\mathrm{O}(6) 1.665(3), \mathrm{V}(2)-\mathrm{O}(3) 1.795(3)$ $\mathrm{V}(2)-\mathrm{O}(4) 1.797(3), \mathrm{V}(2)-\mathrm{O}(7) 1.660(3), \mathrm{V}(2)-\mathrm{O}(8) 1.624(3), \mathrm{Li}(1)-\mathrm{O}(5) 1.930(7), \mathrm{Li}(1)-\mathrm{O}(7)$ 1.962(7), Li(1) - O(7A) 1.950(8), Li(1) - O(9) 1.980(8); O(1) - V(1) - O(2) 107.80(12), O(5) - V(1) - 
$\mathrm{O}(6) 110.17(13), \mathrm{O}(3)-\mathrm{V}(2)-\mathrm{O}(4)$ 105.35(12), $\mathrm{O}(7)-\mathrm{V}(2)-\mathrm{O}(8) 111.78(13), \mathrm{O}(5)-\mathrm{Li}(1)-\mathrm{O}(7)$

109.8(3).

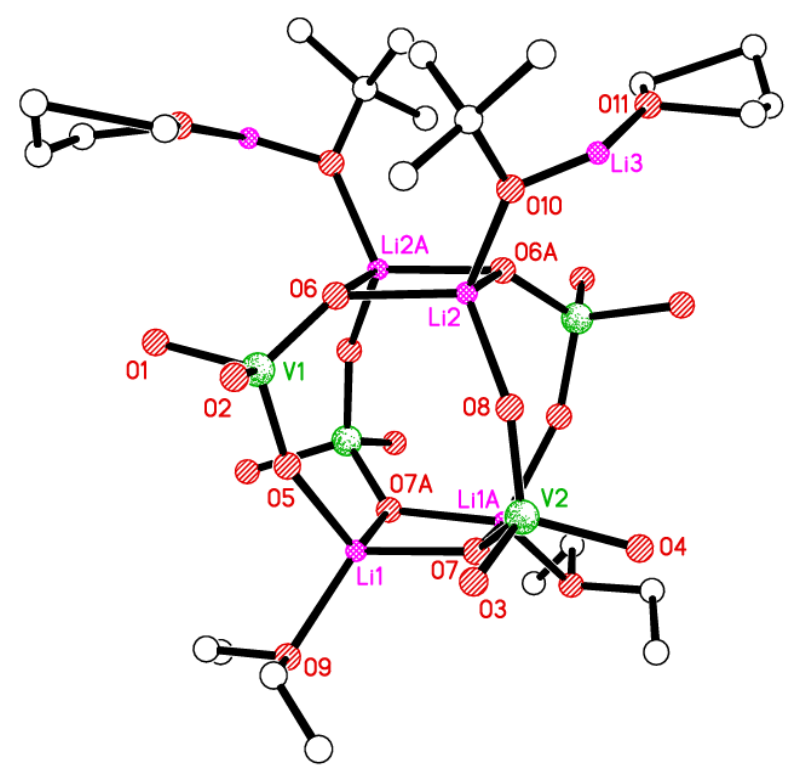

Figure 5. Core of the complex $4 \cdot \mathrm{Et}_{2} \mathrm{O}$.

The molecule $4 \cdot \mathrm{Et}_{2} \mathrm{O}$ lies on a 2-fold axis, so only half is unique. The calixarene is in the 'down, down, out, out, down, down, out, out' conformation. The lithium centres $\operatorname{Li}(1)$ and $\operatorname{Li}(2)$ have four bonds which connect with oxygens of the calixarene, vanadyl-O and tert-butoxide or $\mathrm{Et}_{2} \mathrm{O}$. Each vanadium centre also connects to four oxygens, and together they construct a lantern shape with $\mathrm{Li}_{2} \mathrm{O}_{2}$ diamonds top and bottom and four eight-membered panels around the sides. Li(3) makes two bonds which connect with oxygens of thf and a tert-butoxide. In terms of the charge balance, there are $8 \times \mathrm{O}^{-}$on

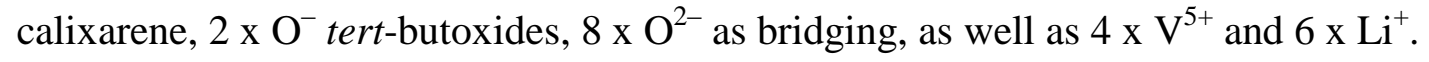

The data suggest that $\mathrm{Li}(3)$ may be replaced by an $\mathrm{H}$ atom which would form an $\mathrm{H}$-bond to $\mathrm{O}(11)$, thereby making this a $t \mathrm{BuOH}$ ligand. In reality, this is likely to be a disordered mixture of $\mathrm{Li}^{+}$and $\mathrm{H}^{+}$ as the $\mathrm{O}-\mathrm{X}$ bond length was too long for $\mathrm{H}^{+}$yet too short for $\mathrm{Li}^{+}$. However, the degree of disorder here 
made developing a stable model with so few electrons impossible. The charge balance would then be: $8 \times \mathrm{O}^{-}$on calixarene, $8 \times \mathrm{O}^{2-}$ as bridging, and $4 \mathrm{x} \mathrm{V}^{5+}, 4 \mathrm{x} \mathrm{Li}^{+}$.

When the 'same reaction' was extracted into acetonitrile $(\mathrm{MeCN})$, the salt complex $\left[\mathrm{Li}(\mathrm{NCMe})_{4}\right]\left[(\mathrm{VO})_{2} \mathrm{~L}^{8} \mathrm{H}\right] \cdot 8 \mathrm{MeCN}(\mathbf{5} \cdot 8 \mathrm{MeCN})$ was isolated. The molecular structure of $\mathbf{5} \cdot 8 \mathrm{MeCN}$ is shown in Figure 6, with selected bond lengths and angles given in the caption. The $\left.\mathrm{Li}(\mathrm{NCMe})_{4}\right]^{+}$cation resides between pairs of anions, lodged in clefts of the calixarene $\mathrm{L}^{8} \mathrm{H}$. These cation/anion/cation/anion chains align parallel to $b$ (see ESI). The MeCN molecules of crystallization also predominantly reside in calixarene clefts.

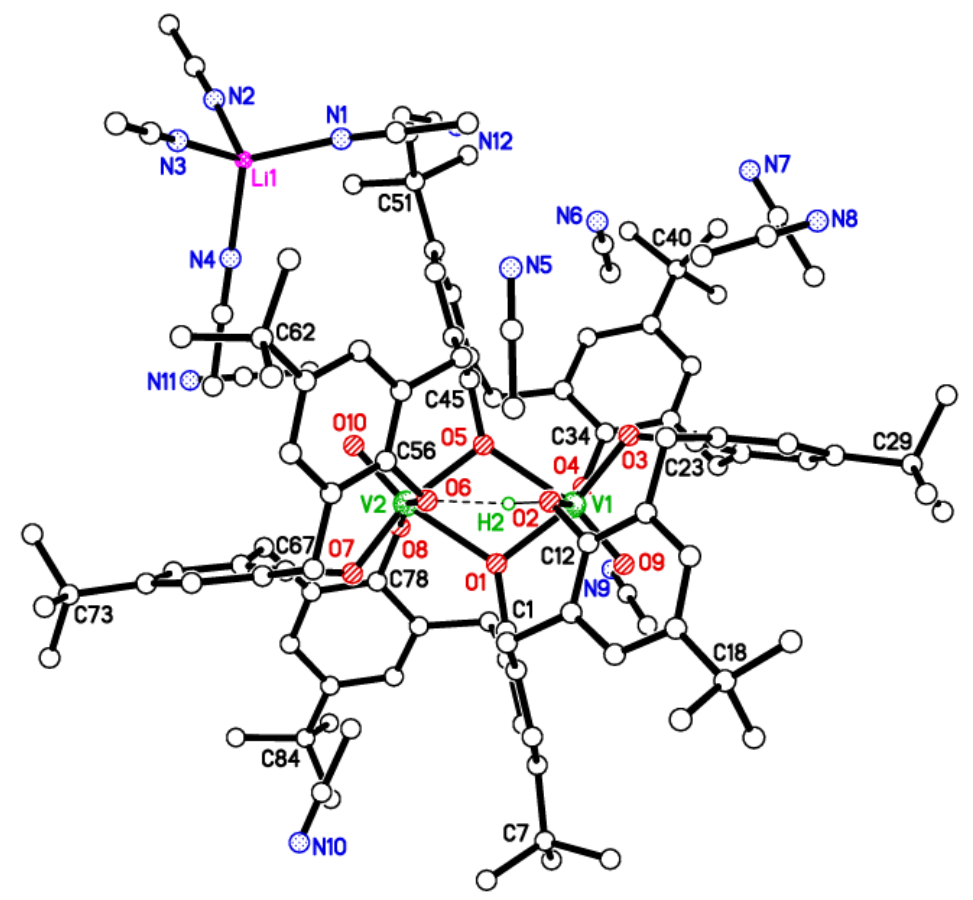

Figure 6. Structure of the salt 5.8MeCN. V(1) - O(1) 1.967(2), V(1) - O(2) 2.095(2), V(1) - O(3) 1.855(2), V(1) - O(4) 1.840(2), V(1) - O(5) 2.205(2); V(1) - O(1) - V(2) 108.78(10), O(1) - V(1) $\mathrm{O}(2)$ 81.76(10), $\mathrm{O}(1)-\mathrm{V}(1)-\mathrm{O}(5) 71.38(9)$. 


\section{Imido complex:}

Use of the imido precursors $\left[\mathrm{V}(\mathrm{N} t-\mathrm{Bu})(\mathrm{O} t-\mathrm{Bu})_{3}\right]$ and $\left[\mathrm{V}(\mathrm{N} p\right.$-tolyl $\left.)(\mathrm{O} t-\mathrm{Bu})_{3}\right]$ in a 1:1 ratio with $\mathrm{L}^{8} \mathrm{H}_{8}$, afforded, via imido exchange, the orange/brown salt $\left[t-\mathrm{BuNH}_{3}\right]\left\{[\mathrm{V}(p \text {-tolylN })]_{2} \mathrm{~L}^{8} \mathrm{H}\right\} \cdot 3 \frac{1}{2} \mathrm{MeCN}(\mathbf{6})$. Crystals of $6 \cdot 3 \frac{1}{2} \mathrm{MeCN}$ suitable for single crystal X-ray diffraction studies were grown from saturated acetonitrile solutions after prolonged standing at $-25{ }^{\circ} \mathrm{C}$. The molecular structure of $\mathbf{7}$ is presented in Figure 7; selected bond lengths and angles are given in Table 3, and are compared with the related complex $\left[\mathrm{V}_{2}(\mathrm{~N} p \text {-tolyl })_{2}\left(\mathrm{H}_{2} \mathrm{~L}^{8}\right)\right] \cdot 41 / 2 \mathrm{MeCN}$. [7a] The anion of 7 adopts a similar local confacial bioctahedral geometry about the two vanadium centres, the latter being linked via asymmetric phenoxide bridges. The calix[8]arene twists such that two sets of three phenoxide subunits each form a small cup and encapsulate an imido group (as highlighted in Figure 7). The $\left[t-\mathrm{BuNH}_{3}\right]^{+}$cation is involved in H-bonding with the calixarene phenoxide oxygen $\mathrm{O}(2)[\mathrm{O}(2) \cdots \mathrm{N}(3)=2.737(5) \AA$, $\left.\mathrm{O}(2) \cdots \mathrm{H}(3 \mathrm{~A})-\mathrm{N}(3)=175^{\circ}\right]$.

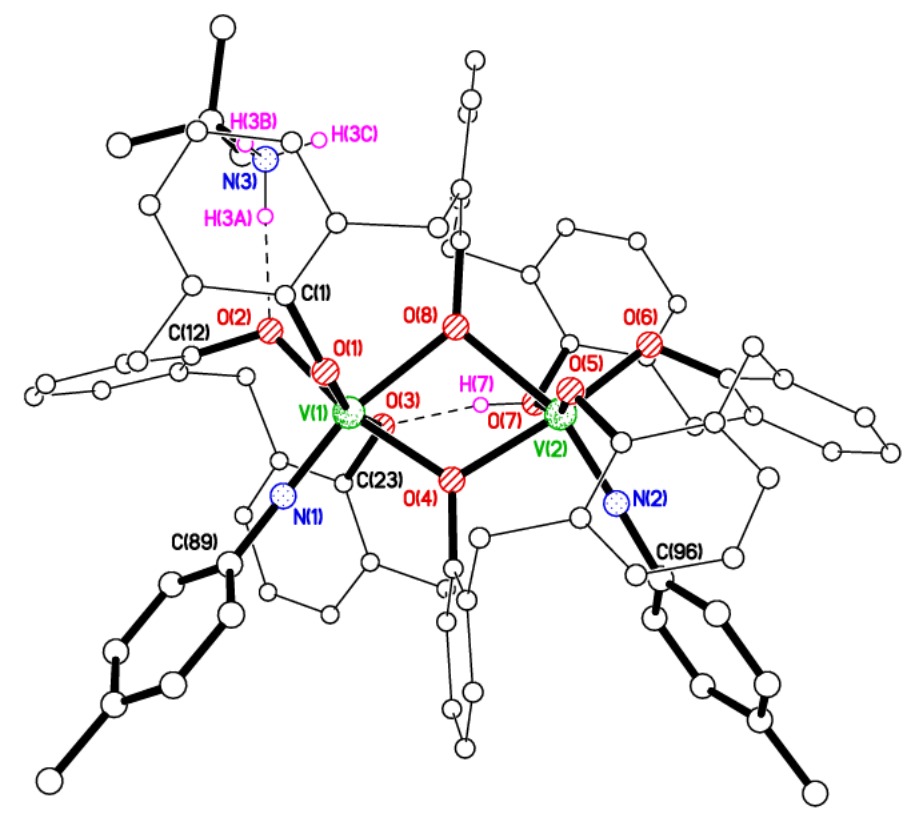


Figure 7. Structure of the salt 6 showing the $\mathrm{V}_{2} \mathrm{O}_{2}$ core and imido groups each encapsulated by three calixarene phenoxide moieties. Hydrogen atoms, except those involved in H-bonding, tert-butyl groups on the calixarene and non-coordinated solvent molecules have been omitted for clarity.

Table 3. Selected structural data for 6 and $\left[\mathrm{V}_{2}(\mathrm{~N} p \text {-tolyl })_{2}\left(\mathrm{H}_{2} \mathrm{~L}^{8}\right)\right] \cdot 41 / 2 \mathrm{MeCN}$

\begin{tabular}{ccc}
\hline $\begin{array}{c}\text { Bond length }(\AA) / \text { Angle } \\
\left({ }^{\circ}\right)\end{array}$ & $\mathbf{6}$ & {$\left[\mathrm{V}_{2}(\mathrm{~N} p \text {-tolyl })_{2}\left(\mathrm{H}_{2} \mathrm{~L}^{8}\right)\right] \cdot 41 / 2 \mathrm{MeCN}$} \\
\hline $\mathrm{V}(1)-\mathrm{O}(1)$ & $1.896(4)$ & $1.890(2)$ \\
$\mathrm{V}(1)-\mathrm{O}(2)$ & $1.922(3)$ & $1.855(2)$ \\
$\mathrm{V}(1)-\mathrm{O}(3)$ & $1.981(4)$ & $2.057(2)$ \\
$\mathrm{V}(1)-\mathrm{O}(4)$ & $1.962(3)$ & $2.002(2)$ \\
$\mathrm{V}(1)-\mathrm{O}(8)$ & $2.162(4)$ & $2.156(2)$ \\
$\mathrm{V}(1)-\mathrm{N}(1)$ & $1.672(4)$ & $1.669(3)$ \\
$\mathrm{V}(2)-\mathrm{N}(2)$ & $1.670(4)$ & $1.667(3)$ \\
$\mathrm{V}(1)-\mathrm{V}(2)$ & $3.3366(13)$ & 3.334 \\
& & $126.7(2)$ \\
$\mathrm{V}(1)-\mathrm{O}(1)-\mathrm{C}(1)$ & $129.6(3)$ & $122.90(19)$ \\
$\mathrm{V}(1)-\mathrm{O}(2)-\mathrm{C}(12)$ & $119.7(3)$ & $120.43(19)$ \\
$\mathrm{V}(1)-\mathrm{O}(3)-\mathrm{C}(23)$ & $118.4(3)$ & $106.31(10)$ \\
$\mathrm{V}(1)-\mathrm{O}(4)-\mathrm{V}(2)$ & $114.38(16)$ & $107.12(19)$ \\
$\mathrm{V}(1)-\mathrm{O}(8)-\mathrm{V}(2)$ & $101.38(14)$ & $175.0(3)$ \\
$\mathrm{V}(1)-\mathrm{N}(1)-\mathrm{C}(89)$ & $172.0(4)$ & $175.0(3)$ \\
$\mathrm{V}(1)-\mathrm{N}(2)-\mathrm{C}(96)$ & $177.7(4)$ &
\end{tabular}

\section{Catalytic screening}

\section{Ethylene}

The complexes 1, 3 and 4 have been screened for their ability to polymerize ethylene in the presence of organoaluminium co-catalysts, namely dimethylaluminium chloride (DMAC) and diethylaluminium 
chloride (DEAC), $\mathrm{Me}_{3} \mathrm{Al}$ (TMA), $\mathrm{Et}_{3} \mathrm{Al}$ (TEA) and dried MAO (DMAO), with or without the reactivating substance ethyltrichloroacetate (ETA) present.

The results are presented in Table 4 and Figure 8, and are further displayed graphically in the ESI (ethylene uptakes). As for other vanadium-based systems, the re-activator ETA is required for high activity. Indeed, it was observed that increasing the amounts of both co-catalyst and ETA present from $5000 \mathrm{Al}: 5000$ ETA to $20000 \mathrm{Al}: 20000$ ETA led to further increased activity. However, the alkylated reagents TMA, TEA and DMAO did not function as co-catalysts. The molecular weights $\left(M_{\mathrm{w}}\right)$ of the polyethylene products isolated were mostly high; but PDIs $\left(M_{\mathrm{w}} / M_{\mathrm{n}}\right)$ of polyethylene products obtained with DEAC/ETA activation at above $80{ }^{\circ} \mathrm{C}$ became higher than those with DMAC/ETA.

\section{Variation of temperature}

For complex 1, using $\mathrm{Me}_{2} \mathrm{AlCl}$ (DMAC) as co-catalyst $(\mathrm{Al} / \mathrm{V}=20,000)$ and in the presence of ethyltrichloroacetate (ETA), the activity peaked at $80{ }^{\circ} \mathrm{C}(163,000 \mathrm{~g} / \mathrm{mmolV} . \mathrm{h})$, whilst further increases in the temperature resulted in a dramatic fall in activity (down to $c a .27,000 \mathrm{~g} / \mathrm{mmolV}$.h at $110{ }^{\circ} \mathrm{C}$ ) and complete inactivity at $140{ }^{\circ} \mathrm{C}$. As noted for other V-based systems, the molecular weight dropped off rapidly on increasing the temperature, although interestingly the PDI $\left(M_{\mathrm{w}} / M_{\mathrm{n}}\right)$ became narrower (tending towards 2.0 at $110{ }^{\circ} \mathrm{C}$ ), suggesting formation of the most stable active species is promoted. On changing the co-catalyst to diethylaluminium chloride (DEAC), the activity peaks ( $c a .73,000$ g/mmolV.h) at the lower temperature of $50{ }^{\circ} \mathrm{C}$ and rapidly drops off on further increasing the temperature. The polymer molecular weight $\left(M_{\mathrm{w}}\right)$ also reduced in value from about 554,000 down to 111,000 over the temperature range 50 to $110{ }^{\circ} \mathrm{C}$. Interestingly, in contrast to the behavior by DMAC/ETA activation, the PDI increased from 4.8 at $50{ }^{\circ} \mathrm{C}$ to over 25.6 at $80{ }^{\circ} \mathrm{C}$, suggesting that multiple centres were active at such higher temperatures. 
Under the same conditions as above, the complex $\mathbf{3}$ was screened. Using DMAC as co-catalyst, the temperature was increased from 50 to $140{ }^{\circ} \mathrm{C}$, which led to a reduction in the activity from 101,000 g/mmolV.h at $50{ }^{\circ} \mathrm{C}$ to $8,240 \mathrm{~g} / \mathrm{mmol} . \mathrm{h}$ at $110{ }^{\circ} \mathrm{C}$; no activity was observed at $140{ }^{\circ} \mathrm{C}$. The molecular weight decreased rapidly on oncreasing the temperature, whilst the PDI actually decreased from $c a .6$ at $50{ }^{\circ} \mathrm{C}$ to a value in the region of 2 to 3 over the temperature range $80-110{ }^{\circ} \mathrm{C}$, the same tedency as 1/DMAC/ETA. Results using DEAC were comparatively poorer, with the observed activity at $80{ }^{\circ} \mathrm{C}$ being about a tenth that observed when using 3/DMAC/ETA; this system was inactive at $110{ }^{\circ} \mathrm{C}$.

The activity displayed by 4 at $50{ }^{\circ} \mathrm{C}$ using DMAC as co-catalyst was similar to that observed for 3 , i.e. ca. $100,000 \mathrm{~g} / \mathrm{mmolV}$.h. The activity of 4 then decreased to about $49,700 \mathrm{~g} / \mathrm{mmolV}$.h at $80{ }^{\circ} \mathrm{C}$, after which it rapidly dropped to about one tenth of this value at $110{ }^{\circ} \mathrm{C}$, similar to that of $3 . M_{\mathrm{w}}$ for $\mathbf{4}$ are relatively higher than those of $\mathbf{1}$ and $\mathbf{3}$, but the-trends observed for-the PDI were analogous to those observed for $\mathbf{1}$ and $\mathbf{3}$. Use as DEAC as co-catalyst again afforded inferior activities to those observed when using DMAC, and there was less control over molecular weight upon DEAC/ETA activation. However, higher $M_{\mathrm{w}} \mathrm{s}$ than those by DMAC/ETA activation resulted from the use of $\mathbf{1}, \mathbf{3}$ and $\mathbf{4}$. Despite the lowering of the observed activity at $110{ }^{\circ} \mathrm{C}$ (to 920), it was found to increase somewhat at $140{ }^{\circ} \mathrm{C}$ to 7,560 g/mmolV.h. Considering with the fact that PDI increases as the temperature raises, different active species from those at low temperature must be generated at $140{ }^{\circ} \mathrm{C}$.

The melting points of the polyethylene obtained from systems employing 1, $\mathbf{3}$ and $\mathbf{4}$ (and the standard catalyst) were all in the range $129.0-136.9^{\circ} \mathrm{C}$, consistent with the formation of linear polyethylene. NMR data for the polymers at the lower end of the melting point range did not show any evidence of branching. Therefore, it is suggested that low $T_{\mathrm{m}}$ is derived from low molecular weight polyethylene.

To benchmark the calixarene catalyst systems decribed above, the complex $\operatorname{VO}(\mathrm{OEt}) \mathrm{Cl}_{2}$ was screened using both DMAC and DEAC as co-catalysts under the same conditions as above. Use of DMAC 
afforded an activity of $74,720 \mathrm{~g} / \mathrm{mmolV} . \mathrm{h}$ at $50{ }^{\circ} \mathrm{C}$, which dropped off only slightly (to 70,800 $\mathrm{g} / \mathrm{mmolV}$.h) on increasing the temperature to $80{ }^{\circ} \mathrm{C}$. However, on further increasing the temperature to $110{ }^{\circ} \mathrm{C}$, the activity fell away (down to $19,360 \mathrm{~g} / \mathrm{mmolV}$.h), which however is higher than observed for $3(8,240 \mathrm{~g} / \mathrm{mmolV} . \mathrm{h})$ and $4(5,240 \mathrm{~g} / \mathrm{mmolV} . \mathrm{h})$ at the same temperature, but lower than that observed for $1(26,700 \mathrm{~g} / \mathrm{mmolV} . \mathrm{h})$. In the case of DEAC, the activity observed at $50{ }^{\circ} \mathrm{C}$ was $96,700 \mathrm{~g} / \mathrm{mmolV} . \mathrm{h}$, which halved at $80{ }^{\circ} \mathrm{C}$ (to $47,440 \mathrm{~g} / \mathrm{mmolV}$.h) and then fell off rapidly at $110{ }^{\circ} \mathrm{C}(17,340 \mathrm{~g} / \mathrm{mmolV} . \mathrm{h})$ and $140{ }^{\circ} \mathrm{C}(3,560 \mathrm{~g} / \mathrm{mmolV} . \mathrm{h})$; of the calixarene systems, only 1 exhibited any activity at $140{ }^{\circ} \mathrm{C}(\mathrm{ca}$. 7,500 $\mathrm{g} / \mathrm{mmolV} . \mathrm{h})$. The general activity trends observed can be summarized as follows: for DMAC, at $50{ }^{\circ} \mathrm{C}, \mathbf{1}>\mathbf{3}$, and $\mathbf{4}>\mathrm{VO}(\mathrm{OEt}) \mathrm{Cl}_{2} ;$ at $80{ }^{\circ} \mathrm{C}, \mathbf{1}>\mathrm{VO}(\mathrm{OEt}) \mathrm{Cl}_{2}, \mathbf{3}>\mathbf{4}$; at $110{ }^{\circ} \mathrm{C}, \mathbf{1}>\mathrm{VO}(\mathrm{OEt}) \mathrm{Cl}_{2}>\mathbf{3}, \mathbf{4}$; at $140{ }^{\circ} \mathrm{C}, \mathbf{4}>\mathrm{VO}(\mathrm{OEt}) \mathrm{Cl}_{2}, \mathbf{3}, \mathbf{4}$; for DEAC, at $50{ }^{\circ} \mathrm{C}, \mathrm{VO}(\mathrm{OEt}) \mathrm{Cl}_{2}>\mathbf{1}>\mathbf{3}>\mathbf{4}$; at $80{ }^{\circ} \mathrm{C}, \mathrm{VO}(\mathrm{OEt}) \mathrm{Cl}_{2}>$ $\mathbf{1 , 3}>\mathbf{4}$; at $110{ }^{\circ} \mathrm{C}, \mathrm{VO}(\mathrm{OEt}) \mathrm{Cl}_{2}>\mathbf{1}>\mathbf{3}, \mathbf{4} ;$ at $140{ }^{\circ} \mathrm{C}, \mathbf{4}>\mathrm{VO}(\mathrm{OEt}) \mathrm{Cl}_{2}>\mathbf{1}, \mathbf{3}$.

\section{Co-polymerization of ethylene with propylene}

The co-polymerization of ethylene with propylene was conducted in the presence of DMAC, DEAC or TMA at $50{ }^{\circ} \mathrm{C}$ over 30 mins. Results are presented in Table 5. For $\mathbf{1}, \mathbf{3}$ and $\mathbf{4}$, best results were obtained using DMAC as co-catalyst, with 1 achieving an activity of 65,100 g/mmolV.h and \%C3 incorporation of $10.9 \mathrm{~mol} \%$. Use of DEAC as co-catalyst afforded lower molecular weights with \%C3 in the range $7.1-8.2 \mathrm{~mol} \%$. However, results using TMA were disappointing (activity $<440 \mathrm{~g} / \mathrm{mmolV} . \mathrm{h}$ ) and so further evaluation using this co-catalyst was discontinued.

In general, the activities of $\mathbf{1}, \mathbf{3}$ and $\mathbf{4}$ were lower than $\mathrm{VO}(\mathrm{OEt}) \mathrm{Cl}_{2}$, whilst the incorporation of propylene was $7.1-10.9 \mathrm{~mol} \%$ was comparable $\left(c f 10 \mathrm{~mol} \%\right.$ for $\left.\mathrm{VO}(\mathrm{OEt}) \mathrm{Cl}_{2}\right)$. Within the calixarene series, the general activity trends observed can be summarized as follows: for DMAC, $\mathbf{1}>\mathbf{3}>\mathbf{4}$ and for DEAC, 1, $3>$ 4. 
Table 4. Ethylene polymerization results ${ }^{\mathrm{a}}$

\begin{tabular}{|c|c|c|c|c|c|c|c|c|c|}
\hline Run & Pre-Cat & Co-Cat & $\mathbf{T}^{c}$ & Yield $^{b}$ & Activity $^{d}$ & $M_{\mathrm{w}}^{\mathrm{e}}$ & $M_{\mathrm{n}}^{\mathrm{e}}$ & PDI & $T_{m}{ }^{f}$ \\
\hline 1 & $\mathrm{VO}(\mathrm{OEt}) \mathrm{Cl}_{2}$ & DMAC & 50 & 0.374 & 74,720 & 946,000 & 169,000 & 5.6 & 134.7 \\
\hline 2 & & & 80 & 0.354 & 70,800 & 138,000 & 45,700 & 3.0 & 133.3 \\
\hline 3 & & & 110 & 0.097 & 19,36 & & & & 134.5 \\
\hline 4 & & & 140 & trace & - & & & & \\
\hline 5 & & DEAC & 50 & 0.483 & 96,700 & 317,000 & 56,800 & 5.6 & 134.4 \\
\hline 6 & & & 80 & 0.237 & 47,440 & 209,000 & 27,200 & 7.7 & 134.0 \\
\hline 7 & & & 110 & 0.087 & 17,340 & & & & 133.8 \\
\hline 8 & & & 140 & 0.018 & 3,560 & & & & 128.9 \\
\hline 10 & 1 & DMAC & 50 & 0.331 & 132,000 & 789,000 & 176,000 & 4.5 & 134.5 \\
\hline 12 & & & 80 & 0.408 & 163,000 & 133,000 & 55,600 & 2.4 & 132.9 \\
\hline 13 & & & 110 & 0.067 & 26,700 & 30,800 & 14,500 & 2.1 & 132.8 \\
\hline 14 & & & 140 & trace & - & & & & \\
\hline 15 & & DEAC & 50 & 0.184 & 73,500 & 554,000 & 115,000 & 4.8 & 131.6 \\
\hline 16 & & & 80 & 0.015 & 6,080 & 316,000 & 12,300 & 25.7 & 132.0 \\
\hline 17 & & & 110 & 0.011 & 4,400 & 112,000 & 5,710 & 19.5 & 130.4 \\
\hline 18 & & & 140 & trace & - & & & & \\
\hline 19 & 3 & DMAC & 50 & 0.251 & 101,000 & 752,000 & 118,000 & 6.4 & 136.5 \\
\hline 20 & & & 80 & 0.202 & 80,800 & 158,000 & 67,700 & 2.3 & 136.9 \\
\hline 21 & & & 110 & 0.021 & 8,240 & 27,300 & 8,550 & 3.2 & 132.8 \\
\hline 22 & & & 140 & trace & - & & & & \\
\hline 23 & & DEAC & 50 & 0.149 & 59,400 & 663,000 & 126,000 & 5.3 & 132.1 \\
\hline 24 & & & 80 & 0.021 & 8,480 & 375,000 & 37,600 & 10.0 & 133.0 \\
\hline 25 & & & 110 & trace & - & & & & \\
\hline 26 & & & 140 & trace & - & & & & \\
\hline 27 & 4 & DMAC & 50 & 0.260 & 104,000 & 945,000 & 190,000 & 5.0 & 136.8 \\
\hline 28 & & & 80 & 0.124 & 49,700 & 272,000 & 86,800 & 3.1 & 134.7 \\
\hline 29 & & & 110 & 0.013 & 5,240 & & & & 133.3 \\
\hline 30 & & & 140 & 0.001 & 480 & & & & 129.0 \\
\hline 31 & & DEAC & 50 & 0.081 & 32,200 & 941,000 & 153,000 & 6.2 & 129.6 \\
\hline 32 & & & 80 & 0.009 & 3,440 & 491,000 & 20,500 & 24.0 & 133.4 \\
\hline 33 & & & 110 & 0.002 & 920 & & & & 130.7 \\
\hline 34 & & & 140 & 0.019 & 7,560 & & & & 132.1 \\
\hline
\end{tabular}

${ }^{a}$ Conditions: 30 minutes, $5 \mathrm{~mL}$ toluene, $0.005 \mu \mathrm{mol} \mathrm{V}, 0.8 \mathrm{MPa}$ ethylene, 20000 equivalents cocatalyst (v V), 20000 equivalents ETA (v V), reaction quenched with isobutylalcohol; ${ }^{b}$ grams, ${ }^{\circ}{ }^{\circ} \mathrm{C},{ }^{\mathrm{d}}$ $(\mathrm{g} /(\mathrm{mmolV} . \mathrm{hr}))$, ${ }^{\mathrm{e}}$ Determined by GPC, reported using polyethylene calibration, ${ }^{\mathrm{f}}{ }^{\circ} \mathrm{C}$ polymer melting point. 


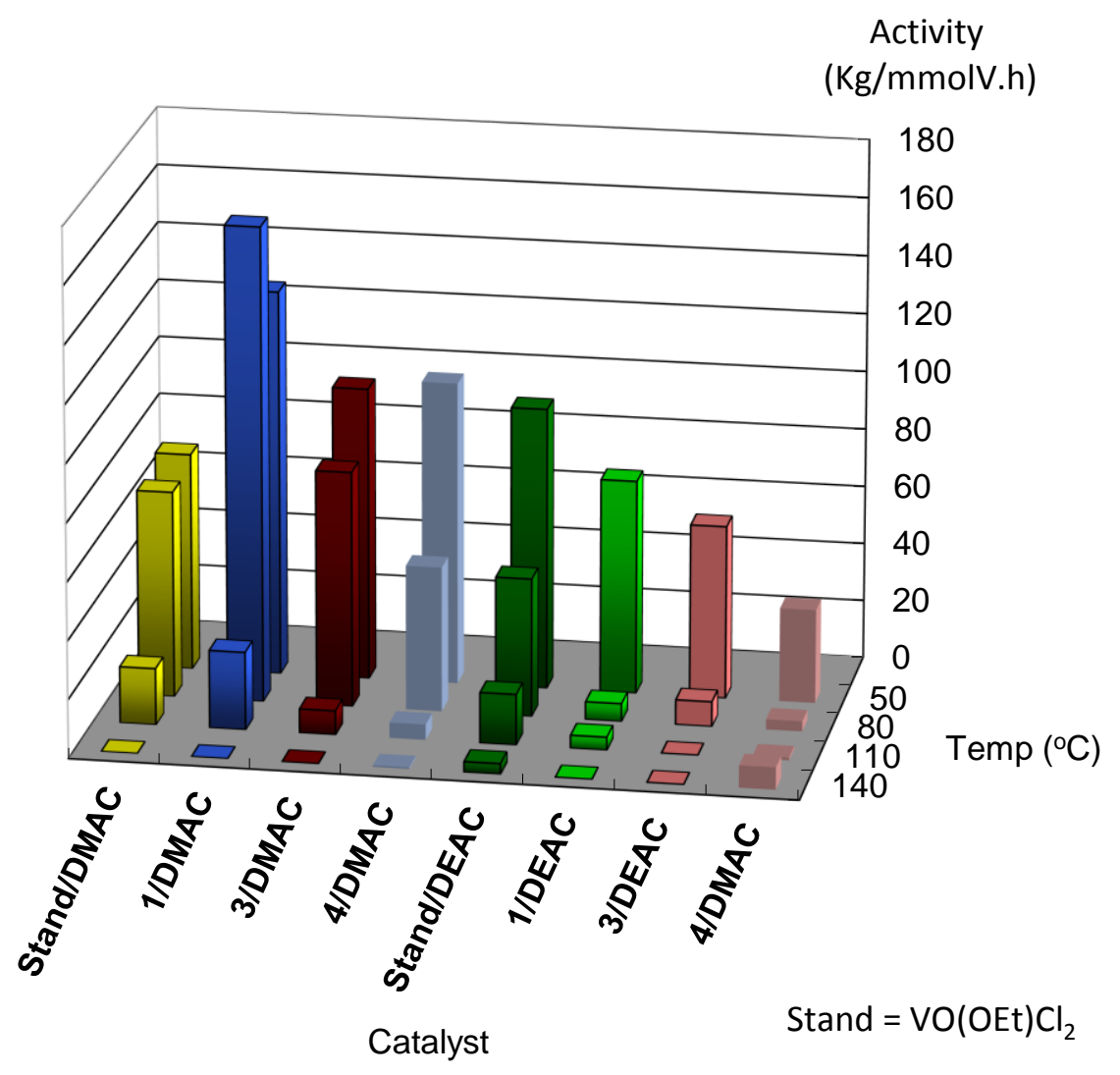

Figure 8. Activity in ethylene polymerization at $50-140{ }^{\circ} \mathrm{C}$ by $\mathrm{VO}(\mathrm{OEt}) \mathrm{Cl}_{2}, \mathbf{1}, \mathbf{3}$, and 4 .

Table 5. Ethylene/propylene co-polymerization results ${ }^{\mathrm{a}}$

\begin{tabular}{|c|c|c|c|c|c|c|c|c|c|}
\hline Run & Pre-Cat & Co-Cat & Yield $^{b}$ & Activity $^{c}$ & $\% \mathrm{C3}^{\mathrm{d}}$ & $M_{\mathrm{w}}^{\mathrm{e}}$ & $M_{\mathrm{n}}^{\mathrm{e}}$ & PDI & $\mathbf{T}_{\mathbf{m}}{ }^{\mathbf{f}}$ \\
\hline 1 & $\operatorname{VO}(\mathrm{OEt}) \mathrm{Cl}_{2}$ & DMAC & 0.391 & 156,000 & 10.0 & 241,000 & 86,600 & 2.8 & 88.9 \\
\hline 2 & & DEAC & 0.191 & 76,400 & 9.1 & 75,700 & 42,700 & 1.8 & 90.2 \\
\hline 3 & 1 & DMAC & 0.163 & 65,100 & 10.9 & 198,000 & 69,500 & 2.9 & 90.3 \\
\hline 4 & & DEAC & 0.070 & 28,000 & 8.2 & 105,000 & 53,000 & 2.0 & 91.9 \\
\hline 5 & & $\mathrm{Me}_{3} \mathrm{Al}$ & 0.0005 & 200 & - & - & - & - & - \\
\hline 6 & 3 & DMAC & 0.105 & 41,800 & 7.8 & 321,000 & 122,000 & 2.6 & 92.9 \\
\hline 7 & & DEAC & 0.071 & 28,200 & 7.8 & 88,700 & 46,800 & 1.9 & 93.7 \\
\hline 8 & & $\mathrm{Me}_{3} \mathrm{Al}$ & 0.001 & 440 & - & - & - & - & - \\
\hline 9 & 4 & DMAC & 0.063 & 25,000 & 7.9 & 264,000 & 120,000 & 2.2 & 92.3 \\
\hline 10 & & DEAC & 0.061 & 24,200 & 7.1 & 127,000 & 45,000 & 2.8 & 91.1 \\
\hline
\end{tabular}

${ }^{a}$ Conditions: $5 \mathrm{~mL}$ toluene, 30 minutes, $50{ }^{\circ} \mathrm{C}, 0.005 \mu \mathrm{mol} \mathrm{V}, 0.4 \mathrm{MPa}$ ethylene, $0.4 \mathrm{MPa}$ propylene, 20000 equivalents co-catalyst (v V), 20000 equivalents ETA (v V), reaction quenched with isobutylalcohol; ${ }^{b}$ grams, ${ }^{\mathrm{c}}(\mathrm{g} /(\mathrm{mmolV} . \mathrm{hr})),{ }^{\mathrm{d}} \mathrm{Mol} \%$ determined by FT-IR. ${ }^{\mathrm{e}}$ Determined by GPC, reported using polyethylene calibration, ${ }^{\mathrm{f}}{ }^{\circ} \mathrm{C}$ polymer melting point. 


\section{Conclusion}

In conclusion, use of the heterobimetallic complexes $\left[\mathrm{MVO}(\mathrm{O} t \mathrm{Bu})_{4}\right](\mathrm{M}=\mathrm{Na}, \mathrm{K})$, formed in-situ from $\mathrm{VOCl}_{3}$ and $\mathrm{MO} t \mathrm{Bu}$, with p-tert-butylcalix[8]arene led to the formation of highly crystalline vanadium complexes, which adopt intriguing structural motifs (shallow saddle-shaped for $\mathbf{1}$ and $\mathbf{3}$; pleated loop for 2), often stabilized by the presence of alkali metal cations. In the case of lithium, it only proved possible to isolate crystalline products when the addition was reversed such that $\mathrm{VOCl}_{3}$ was added to a pre-mixed solution of p-tert-butylcalix[8] arene and $\mathrm{LiO} t \mathrm{Bu}$. The products when using lithium contain, in the case of 4 , a central lantern-type cage capped top and bottom by an $\mathrm{Li}_{2} \mathrm{O}_{2}$ diamond with the calix[8]arene adopting a in a 'down, down, out, out, down, down, out, out' conformation, or a shallow saddle-shaped conformation (as in 5).

For the polymerization of ethylene, using either DMAC or DEAC as co-catalyst and the re-activator ETA, the systems were all highly active, producing high molecular weight linear polyethylene. In most cases, activities were lower than the standard catalyst $\mathrm{VO}(\mathrm{OEt}) \mathrm{Cl}_{2}$ though some properties of the calixarene systems proved noteworthy, namely the activity of 4 at $140{ }^{\circ} \mathrm{C}$ surpassed that of the benchmark catalyst and secondly, in some instances the calixarene-based systems gave products of higher molecular weight than $\mathrm{VO}(\mathrm{OEt}) \mathrm{Cl}_{2}$ but with comparable activity, which may be an advantage for industrial use.

\section{Experimental}

\section{General:}

All manipulations were carried out under an atmosphere of dry nitrogen using conventional Schlenk and cannula techniques or in a conventional nitrogen-filled glove box. Diethyl ether and tetrahydrofuran were refluxed over sodium and benzophenone. Toluene was refluxed over sodium. 
Dichloromethane and acetonitrile were refluxed over calcium hydride. All solvents were distilled and degassed prior to use. IR spectra (nujol mulls, $\mathrm{KBr}$ or $\mathrm{NaCl}$ windows) were recorded on a Nicolet Avatar 360 FT IR spectrometer; ${ }^{1} \mathrm{H}$ NMR spectra were recorded at room temperature on a Varian VXR $400 \mathrm{~S}$ spectrometer at $400 \mathrm{MHz}$ or a Gemini 300 NMR spectrometer or a Bruker Advance DPX-300 spectrometer at $300 \mathrm{MHz}$. The ${ }^{1} \mathrm{H}$ NMR spectra were calibrated against the residual protio impurity of the deuterated solvent. Elemental analyses were performed by the elemental analysis service at the London Metropolitan University. The ligand $\mathrm{L}^{8} \mathrm{H}_{8}$ was prepared as described in the literature. [13] The precursors $\left[\mathrm{V}(\mathrm{NR})(\mathrm{O} t \mathrm{Bu})_{3}\right]$ were prepared via $\mathrm{K} t \mathrm{OBu}$ using the method of Maatta. [14] For the polymerization studies, the dry toluene employed as a polymerization solvent was purified by passage through columns of activated alumina and BASF R3-11 oxygen scavenger. Methylaluminoxane (MAO) was purchased from Albemarle Corporation as a 1.2 M toluene solution. This solution was dried under vacuum to remove the toluene and a substantial fraction of the $\mathrm{AlMe}_{3}$, to produce "dried MAO " (DMAO). Ethylene was obtained from Sumitomo Seika Co.

\section{Synthesis of $\left[\mathrm{Na}(\mathrm{NCMe})_{5}\right]\left[(\mathrm{VO})_{2} \mathrm{~L}^{8} \mathrm{H}\right] \cdot 4 \mathrm{MeCN}(\mathbf{1} \cdot 4 \mathrm{MeCN})$}

The salt $\left[\mathrm{NaVO}(\mathrm{O} t-\mathrm{Bu})_{4}\right]$ (formed in-situ from $\mathrm{VOCl}_{3} 0.27 \mathrm{~cm}^{3}, 2.89 \mathrm{mmol}$ and $\mathrm{NaO} t-\mathrm{Bu} 1.12 \mathrm{~g}, 11.65$ mmol) and p-tert-butylcalix[8]arene $\mathrm{H}_{8}, \mathrm{~L}^{8} \mathrm{H}_{8}(1.87 \mathrm{~g}, 1.44 \mathrm{mmol})$ were refluxed in toluene (30 ml) for $12 \mathrm{~h}$. Following removal of volatiles in-vacuo, the residue was extracted into hot (heat gun) acetonitrile (30 ml), affording 1 as brown blocks on prolonged standing (1 -2 days) at ambient temperature. Yield: $1.23 \mathrm{~g}, 47 \%$; elemental analysis (sample dried in-vacuo for $12 \mathrm{~h}$ ) calculated for $\mathbf{1} \cdot 4 \mathrm{CH}_{3} \mathrm{CN}-5 \mathrm{MeCN}$, $\mathrm{C}_{96} \mathrm{H}_{117} \mathrm{~N}_{4} \mathrm{NaO}_{10} \mathrm{~V}_{2}$ : C 71.5, H 7.3, N $3.5 \%$; found: C 70.5, H 6.8, N $3.5 \%$ [15]; IR (nujol mull, $\mathrm{KBr}$ ): 3176w, 2263w, 1733w, 1610w, 1293s, 1260s, 1203s, 1153m, 1093s, 1018s, 967s, 911m, 869m, 808s, 722s, 670w, 633w, 581w, 572w, 553w, 534w, 521w, 464w, 448w, 430w. MS (ESI): $\mathrm{m} / z 1589[\mathrm{M}]^{+}$ $\mathrm{Na}(\mathrm{NCMe})_{5} .{ }^{1} \mathrm{H} \mathrm{NMR}\left(\mathrm{CDCl}_{3}, 400 \mathrm{MHz}\right): 15.49$ (Br, s, O-H-O, 1H) 7.30 (s, 4H, arylH ), 7.21 (s, 6H, 
$\operatorname{aryl} H), 7.17(\mathrm{~s}, 2 \mathrm{H}, \operatorname{aryl} H), 7.06(\mathrm{~s}, 2 \mathrm{H}, \operatorname{aryl} H), 6.97(\mathrm{~s}, 2 \mathrm{H}, \operatorname{aryl} H), 5.97\left(\mathrm{~d}, 2 \mathrm{H},{ }^{2} \mathrm{~J}_{\mathrm{HH}}=12.6 \mathrm{~Hz}\right.$, endo$\left.\mathrm{CH}_{2}\right), 5.66\left(\mathrm{~d}, 4 \mathrm{H},{ }^{2} J_{\mathrm{HH}}=13.7 \mathrm{~Hz}\right.$, endo- $\left.\mathrm{CH}_{2}\right), 4.66\left(\mathrm{~d}, 2 \mathrm{H},{ }^{2} J_{\mathrm{HH}}=11.8 \mathrm{~Hz}\right.$, endo- $\left.\mathrm{CH}_{2}\right), 3.54(\mathrm{~d}, 2 \mathrm{H}$, ${ }^{2} J_{\mathrm{HH}}=13.5 \mathrm{~Hz}$, exo-C $\left.\mathrm{CH}_{2}\right), 3.49\left(\mathrm{~d}, 2 \mathrm{H},{ }^{2} J_{\mathrm{HH}}=12.3 \mathrm{~Hz}\right.$, exo-C $\left.\mathrm{CH}_{2}\right), 3.38\left(\mathrm{~d}, 2 \mathrm{H},{ }^{2} J_{\mathrm{HH}}=13.7 \mathrm{~Hz}\right.$, exo$\left.\mathrm{CH}_{2}\right), 3.30\left(\mathrm{~d}, 2 \mathrm{H},{ }^{2} J_{\mathrm{HH}}=11.8 \mathrm{~Hz}\right.$, exo- $\left.\mathrm{CH}_{2}\right), 1.30$ (overlapping s, $\left.72 \mathrm{H}, \mathrm{C}\left(\mathrm{CH}_{3}\right)_{3}\right){ }^{51} \mathrm{~V} \mathrm{NMR}\left(\mathrm{CDCl}_{3}\right) \delta$ : $-202.4\left(\omega^{1} / 2700 \mathrm{~Hz}\right),-333.8\left(\omega^{1} / 2500 \mathrm{~Hz}\right)$.

Synthesis of $\left\{\left[\left(\mathrm{Na}(\mathrm{VO})_{4} \mathrm{~L}^{8}\right)(\mathrm{Na}(\mathrm{NCMe}))_{3}\right]\left[\mathrm{Na}(\mathrm{NCMe})_{6}\right]\right\}_{2} \cdot 10 \mathrm{MeCN}(\mathbf{2} \cdot 10 \mathrm{MeCN})$

As for 1, but using [ $\left.\mathrm{NaVO}(\mathrm{O} t-\mathrm{Bu})_{4}\right]\left(\left[\mathrm{VOCl}_{3}\right] 0.27 \mathrm{~cm}^{3}, 2.89 \mathrm{mmol}\right.$ and $\left.\mathrm{NaOt}-\mathrm{Bu} 1.12 \mathrm{~g}, 11.65 \mathrm{mmol}\right)$ and $\mathrm{L}^{8} \mathrm{H}_{8}$ (0.93 g, $0.72 \mathrm{mmol}$ ), affording 2 as yellow blocks. Yield: $0.57 \mathrm{~g}, 17 \%$; elemental analysis calculated for $5 \cdot 10 \mathrm{CH}_{3} \mathrm{CN}, \mathrm{C}_{212} \mathrm{H}_{262} \mathrm{~N}_{18} \mathrm{Na}_{8} \mathrm{O}_{32} \mathrm{~V}_{8} \cdot 10 \mathrm{C}_{2} \mathrm{H}_{3} \mathrm{~N}$ : C 60.9, $\mathrm{H}$ 6.4, N $8.6 \%$; found: $\mathrm{C}$ 61.0, $\mathrm{H}$ 6.5, N $8.5 \%$; IR (nujol mull, KBr): v 2320w, 1604w, 1300w, 1261s, 1204w, 1094bs, 1019bs, 916w, 866w, 800s, 722m, 702w, 660w; MS (solvent free MALDI, DCTB matrix) $m / z: 3200\left(\mathrm{M}^{+}-10 \mathrm{MeCN}\right.$ $\left.-2 \mathrm{Na}(\mathrm{MeCN})_{6}-2 \mathrm{Na}(\mathrm{MeCN})_{3}-3 \mathrm{Na}-\mathrm{VO}\right), 3159\left(\mathrm{M}^{+}-11 \mathrm{MeCN}-2 \mathrm{Na}(\mathrm{MeCN})_{6}-2 \mathrm{Na}(\mathrm{MeCN})_{3}-\right.$ $3 \mathrm{Na}-\mathrm{VO}) .{ }^{1} \mathrm{H} \mathrm{NMR}\left(\mathrm{CDCl}_{3}\right.$, sample dried for $\left.12 \mathrm{~h}\right) \delta: 7.25(\mathrm{~m}, 4 \mathrm{H}, \operatorname{aryl} H), 7.23(\mathrm{~m}, 6 \mathrm{H}$, aryl $H)$, 7.18(m, 4H, aryl $H), 7.09($ br s, 6H, $\operatorname{aryl} H), 7.06(\mathrm{~m} \mathrm{4H}, \operatorname{aryl} H), 7.05\left(\mathrm{~d}, 4 \mathrm{H}, J_{\mathrm{HH}}=1.50 \mathrm{~Hz}, \operatorname{aryl} H\right)$, $7.02($ br s, $2 \mathrm{H}, \operatorname{aryl} H), 6.94\left(\mathrm{~m}, 2 \mathrm{H}, J_{\mathrm{HH}}=1.99 \mathrm{~Hz}, \operatorname{aryl} H\right), 6.15\left(\mathrm{~d},{ }^{2} J_{\mathrm{HH}} 14.5 \mathrm{~Hz}, 2 \mathrm{H}\right.$, endo-C $\left.\mathrm{CH}_{2}\right), 5.36$ $\left(\mathrm{d},{ }^{2} J_{\mathrm{HH}} 14.0 \mathrm{~Hz}, 4 \mathrm{H}\right.$, endo- $\left.\mathrm{CH}_{2}\right), 5.15\left(\mathrm{~d},{ }^{2} J_{\mathrm{HH}} 13.0 \mathrm{~Hz}, 4 \mathrm{H}\right.$, endo- $\left.\mathrm{CH}_{2}\right), 4.62$ (overlapping d, J obscured, $4 \mathrm{H}$, endo- $\left.\mathrm{CH}_{2}\right), 4.38\left(\mathrm{~d},{ }^{2} J_{\mathrm{HH}} 13.2 \mathrm{~Hz}, 2 \mathrm{H}\right.$, endo- $\left.\mathrm{CH}_{2}\right), 3.64\left(\mathrm{~d},{ }^{2} J_{\mathrm{HH}} 14.5 \mathrm{~Hz}, 2 \mathrm{H}\right.$, exo-C $\left.\mathrm{CH}_{2}\right)$, $3.54\left(\mathrm{~d},{ }^{2} J_{\mathrm{HH}} 14.2 \mathrm{~Hz}, 2 \mathrm{H}\right.$, exo-CH$), 3,43\left(\mathrm{~d},{ }^{2} \mathrm{~J}_{\mathrm{HH}} 12.1 \mathrm{~Hz}, 2 \mathrm{H}\right.$, exo-CH$), 3.24(\mathrm{~d}, \mathrm{~J}$ obscured, $2 \mathrm{H}$, exo-CH $\left.\mathrm{CH}_{2}\right), 3.23\left(\mathrm{~d},{ }^{2} J_{\mathrm{HH}} 14.0 \mathrm{~Hz}, 4 \mathrm{H}\right.$, exo-C $\left.\mathrm{CH}_{2}\right), 2.98\left(\mathrm{~d},{ }^{2} J_{\mathrm{HH}} 13.2 \mathrm{~Hz}, 2 \mathrm{H}\right.$, exo-C $\left.\mathrm{C}_{2}\right), 2.84 \mathrm{~d},{ }^{2} J_{\mathrm{HH}} 13.0$ $\mathrm{Hz}, 2 \mathrm{H}$, exo- $\left.\mathrm{CH}_{2}\right), 1.24\left(\mathrm{~s}, 18 \mathrm{H}, \mathrm{C}\left(\mathrm{CH}_{3}\right)_{3}\right), 1.21\left(\mathrm{~s}, 36 \mathrm{H}, \mathrm{C}\left(\mathrm{CH}_{3}\right)_{3}\right), 1.18\left(\mathrm{~s}, 18 \mathrm{H}, \mathrm{C}\left(\mathrm{CH}_{3}\right)_{3}\right), 1.05(\mathrm{~s}$, 18H, $\left.\mathrm{C}\left(\mathrm{CH}_{3}\right)_{3}\right), 1.03\left(\mathrm{~s}, 36 \mathrm{H}, \mathrm{C}\left(\mathrm{CH}_{3}\right)_{3}\right), 1.01\left(\mathrm{~s}, 18 \mathrm{H}, \mathrm{C}\left(\mathrm{CH}_{3}\right)_{3}\right) .{ }^{51} \mathrm{~V}$ NMR $\left(105.1 \mathrm{MHz}, \mathrm{CDCl}_{3}\right) \delta$ : $481.2\left(\omega^{1} / 2585 \mathrm{~Hz}\right)$. 
Synthesis of $\left[(\mathrm{VO})_{4} \mathrm{~L}^{8}\left(\mu^{3}-\mathrm{O}\right)_{2}\right] \cdot 3 \mathrm{MeCN}$ and $\mathbf{3} \cdot 3 \mathrm{CH}_{2} \mathrm{Cl}_{2}$

As for 1, but using [ $\left.\mathrm{VO}(\mathrm{Ot}-\mathrm{Bu})_{3}\right]\left(\mathrm{VOCl}_{3} 0.27 \mathrm{~cm}^{3}, 2.89 \mathrm{mmol}\right.$ and $\left.\mathrm{KO} t-\mathrm{Bu} 1.03 \mathrm{~g}, 8.67 \mathrm{mmol}\right)$ and $\mathrm{L}^{8} \mathrm{H}_{8}(0.93 \mathrm{~g}, 0.72 \mathrm{mmol})$, affording $\mathbf{6} \cdot 3 \mathrm{CH}_{3} \mathrm{CN}$ as black blocks. Yield: $0.47 \mathrm{~g}, 38 \%$; elemental analysis calculated for 3.3 $\mathrm{CH}_{3} \mathrm{CN} \mathrm{C}_{88} \mathrm{H}_{104} \mathrm{~V}_{4} \mathrm{O}_{14} \cdot 3 \mathrm{C}_{2} \mathrm{H}_{3} \mathrm{~N}$ : C 65.9, H 6.7, N $2.5 \%$; found: $\mathrm{C} 65.7, \mathrm{H}$ 6.3, N $3.2 \%$; IR (nujol mull, $\mathrm{cm}^{-1}, \mathrm{KBr}$ ): 1594w, 1567w, 1303w, 1288w, 1260s, 1226w, 1201m, 1172w, 1098bs, 1022s, 944w, 913w, 875m, 833m, 794s, 734w, 705w, 670w, 653m, 642w, 617w, 574w. MS: (MALDI): $\left[\mathrm{MH}^{+}\right] 1589.6$ (solvent free) $\mathrm{m} / z, 1529.5\left[\mathrm{MH}^{+}\right]-\mathrm{VO}, 1488.5\left[\mathrm{MH}^{+}\right]-2 \mathrm{~V} .{ }^{1} \mathrm{H}$ $\operatorname{NMR}\left(\mathrm{C}_{6} \mathrm{D}_{6}\right.$, sample dried for $\left.12 \mathrm{~h}\right) \delta: 7.34-6.96$ (overlapping m, 16H, Aryl $\left.H\right), 5.05\left(\mathrm{~d},{ }^{2} J_{\mathrm{HH}} 11.7 \mathrm{~Hz}\right.$, $2 \mathrm{H}$, endo- $\left.\mathrm{CH}_{2}\right), 4.89^{2} J_{\mathrm{HH}} 14.4 \mathrm{~Hz}, 4 \mathrm{H}$, endo- $\left.\mathrm{CH}_{2}\right), 4.29{ }^{2} J_{\mathrm{HH}} 12.6 \mathrm{~Hz}, 2 \mathrm{H}$, endo- $\left.\mathrm{CH}_{2}\right), 3.14\left(\mathrm{~d},{ }^{2} J_{\mathrm{HH}}\right.$ $12.6 \mathrm{~Hz}, 2 \mathrm{H}$, exo-CH ), $2.98-2.92$ (overlapping m, J obscured, 4H, exo-CH$)_{2}$ ), $2.55\left(\mathrm{~d},{ }^{2} J_{\mathrm{HH}} 14.4 \mathrm{~Hz}\right.$, $2 \mathrm{H}$, exo- $\left.\mathrm{CH}_{2}\right), 0.95\left(\mathrm{~s}, 36 \mathrm{H}, \mathrm{C}\left(\mathrm{CH}_{3}\right)_{3}\right), 0.74\left(\mathrm{~s}, 36 \mathrm{H}, \mathrm{C}\left(\mathrm{CH}_{3}\right)_{3}\right), 0.28$ (s, 3H MeCN). ${ }^{51} \mathrm{~V} \mathrm{NMR}\left(\mathrm{CDCl}_{3}\right)$

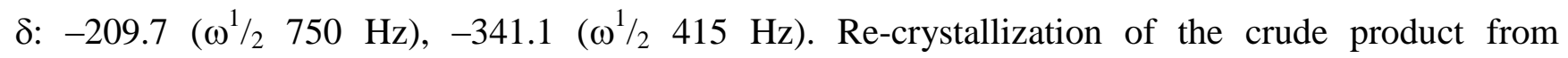
dichloromethane afforded dark green rod-like crystals of $3 \cdot 3 \mathrm{CH}_{2} \mathrm{Cl}_{2}$. Yield: $0.41 \mathrm{~g}, 31 \%$; elemental analysis calculated for $3 \cdot 3 \mathrm{CH}_{2} \mathrm{Cl}_{2}: \mathrm{C}_{88} \mathrm{H}_{104} \mathrm{~V}_{4} \mathrm{O}_{14}$ (solvent free): C 59.3, H 6.0; found: C 59.4, H 5.9\%;

${ }^{51} \mathrm{~V} \mathrm{NMR}\left(\mathrm{CDCl}_{3}\right) \delta:-213.6\left(\omega^{1 / 2} 1500 \mathrm{~Hz}\right),-341.2\left(\omega^{1} / 2330 \mathrm{~Hz}\right),-371.2$.

Synthesis of $\left\{\left(\mathrm{VO}_{2}\right)_{2} \mathrm{Li}_{6}\left[\mathrm{~L}^{8}\right](\operatorname{thf})_{2}(\mathrm{O} t \mathrm{Bu})_{2}\left(\mathrm{Et}_{2} \mathrm{O}\right)_{2}\right\} \cdot \mathrm{Et}_{2} \mathrm{O}\left(\mathbf{4} \cdot \mathrm{Et}_{2} \mathrm{O}\right)$

To $\mathrm{L}^{8} \mathrm{H}_{8}(1.00 \mathrm{~g}, 0.77 \mathrm{mmol})$ in $\mathrm{THF} / \mathrm{Et}_{2} \mathrm{O}(1: 1 ; 30 \mathrm{ml})$ was added a solution of $\mathrm{LiO} t \mathrm{Bu}(8.01 \mathrm{ml}, 1.0$ $\mathrm{M}, 8.01 \mathrm{mmol})$ at ambient temperature and stirred for $2 \mathrm{~h}$. The system was then cooled to $-78{ }^{\circ} \mathrm{C}$ and $\operatorname{VOCl}_{3}(0.15 \mathrm{ml}, 1.59 \mathrm{mmol})$ was slowly added and the system was allowed to warm to ambient temperature and stirred for $12 \mathrm{~h}$. Filtration and concentration to about two thirds the volume afforded orange prisms on prolonged standing at $0{ }^{\circ} \mathrm{C}$. Yield: $0.74 \mathrm{~g}, 44.0 \%$; elemental analysis calculated for 4. $\mathrm{Et}_{2} \mathrm{O} \mathrm{C}{ }_{112} \mathrm{H}_{160} \mathrm{Li}_{6} \mathrm{O}_{22} \mathrm{~V}_{4} \cdot\left(\mathrm{C}_{4} \mathrm{H}_{8} \mathrm{O}\right.$ ): C 64.0, H $7.9 \%$; found: $\mathrm{C}$ 63.7, H $7.8 \%$; IR (nujol mull, $\mathrm{cm}^{-1}$, 
$\mathrm{NaCl}): 1599 \mathrm{w}, 1573 \mathrm{w}, 1414 \mathrm{w}, 364 \mathrm{~m}, 1303 \mathrm{w}, 1290 \mathrm{w}, 1259 \mathrm{~s}, 1202 \mathrm{w}, 1184 \mathrm{w}, 1093 \mathrm{bs}, 1020 \mathrm{bs}, 944 \mathrm{w}$ 893w, 880w, 867w, 799s, 722w, 687w, 670w, 625w, 613w, 595w, 570w, 549w, 536w. MS (EI positive mode) $m / z, 2101.8\left[\mathrm{M}^{+}\right]-\mathrm{Et}_{2} \mathrm{O}, 1885.5\left[\mathrm{M}^{+}\right]-\mathrm{Et}_{2} \mathrm{O}-\mathrm{THF}, 1774.6\left[\mathrm{M}^{+}\right]-\mathrm{Et}_{2} \mathrm{O}-\mathrm{THF}-5 \mathrm{Li} ;{ }^{1} \mathrm{H}$ $\operatorname{NMR}\left(\mathrm{CDCl}_{3}\right)$ ): $7.28-6.95$ (overlapping m, $\left.16 \mathrm{H}, \operatorname{aryl} H\right), 4.63\left(\mathrm{~d}, 2 \mathrm{H},{ }^{2} \mathrm{~J}_{\mathrm{HH}} 12.0 \mathrm{~Hz}\right.$, endo- $\left.\mathrm{CH}_{2}\right), 4.35$ (overlapping d, 6H, endo- $\mathrm{CH}_{2}$ ), 3.86 and 3.66 (2x bs, 20H, $\mathrm{OCH}_{2}$ of $3 \mathrm{x} \mathrm{Et}_{2} \mathrm{O}, 2 \mathrm{x}$ THF), 3.47 (d, 2H, ${ }^{2} J_{\mathrm{HH}} 16.0 \mathrm{~Hz}$, exo-CH$), 3.39\left(\mathrm{~d}, 2 \mathrm{H},{ }^{2} J_{\mathrm{HH}} 12.0 \mathrm{~Hz}\right.$, exo-CH 2$), 3.34$ (d, 4H, ${ }^{2} J_{\mathrm{HH}} 12.0 \mathrm{~Hz}$, exo- $\left.\mathrm{CH}_{2}\right)$, 1.78 (bs, 8H, $\mathrm{CH}_{2}$ of 2x THF), 1.52 (s, $\left.18 \mathrm{H}, \mathrm{OC}\left(\mathrm{CH}_{3}\right)_{3}\right), 1.48$ (s, $\left.72 \mathrm{H}, \mathrm{C}\left(\mathrm{CH}_{3}\right)_{3}\right), 1.25$ (overlapping m, $18 \mathrm{H}, \mathrm{OCH}_{2} \mathrm{CH}_{3}$ of $\left.3 \mathrm{x} \mathrm{Et}_{2} \mathrm{O}\right) .{ }^{51} \mathrm{~V} \mathrm{NMR}\left(\mathrm{CDCl}_{3}\right) \delta:-672.1,-694.0$.

\section{Synthesis of $\left[\mathrm{Li}(\mathrm{NCMe})_{4}\right]\left[(\mathrm{VO})_{2} \mathrm{~L}^{8} \mathrm{H}\right] \cdot 8 \mathrm{MeCN}(5 \cdot 8 \mathrm{MeCN})$}

As for 4, but following removal of THF, the residue was extracted into hot MeCN (30 ml). Yield: $1.02 \mathrm{~g}$, $68.9 \%$; elemental analysis calculated for $5 \cdot 8 \mathrm{MeCN} \mathrm{C}_{88} \mathrm{H}_{105} \mathrm{O}_{10} \mathrm{~V}_{2} \cdot \mathrm{C}_{8} \mathrm{H}_{12} \mathrm{LiN}_{4}{ }^{+} \cdot 8\left(\mathrm{C}_{2} \mathrm{H}_{3} \mathrm{~N}\right)$ : C 69.9, H 7.4, N $8.7 \%$; found: C 69.3, H 7.2, N $8.5 \%$; IR (nujol mull, $\mathrm{cm}^{-1}, \mathrm{NaCl}$ ): 1573w, 1453s, 1415s, 1316s, 1292s, 1260s, 1201s, 1116s, 1094s, 1023s, 966s, 911m, 869m, 834m, 818s, 806s, 780m, 750m, 725m, 673w, 634w. MS (ESI): $1923\left(\mathrm{M}^{+}-\mathrm{H}\right), 1876\left(\mathrm{M}^{+}-\mathrm{Li}-\mathrm{MeCN}\right), 1712\left(\mathrm{M}^{+}-\mathrm{Li}-\right.$ 5MeCN), $1630\left(\mathrm{M}^{+}-\mathrm{Li}-7 \mathrm{MeCN}\right), 1589\left(\mathrm{M}^{+}-\mathrm{Li}-8 \mathrm{MeCN}\right), 1548\left(\mathrm{M}^{+}-\mathrm{Li}-9 \mathrm{MeCN}\right), 1507\left(\mathrm{M}^{+}-\right.$ $\mathrm{Li}-10 \mathrm{MeCN}), 1425\left(\mathrm{M}^{+}-\mathrm{Li}-12 \mathrm{MeCN}\right) .{ }^{1} \mathrm{H} \mathrm{NMR}\left(\mathrm{CD}_{3} \mathrm{CN}\right.$, sample dried for $\left.12 \mathrm{~h}\right) \delta: 7.33\left(\mathrm{~m}, J_{\mathrm{HH}}\right.$ $4.0 \mathrm{~Hz}, 2 \mathrm{H}, \operatorname{arylH}), 7.26$ (overlapping m, $4 \mathrm{H}, \operatorname{arylH}), 7.23$ (overlapping m, $2 \mathrm{H}, \operatorname{arylH}), 7.20\left(\mathrm{~m}, J_{\mathrm{HH}}\right.$ $4.0 \mathrm{~Hz}, 2 \mathrm{H}, \operatorname{aryl} H), 7.18\left(\mathrm{~m}, J_{\mathrm{HH}} 4.0 \mathrm{~Hz}, 2 \mathrm{H}, \operatorname{aryl} H\right), 7.00\left(\mathrm{~m}, J_{\mathrm{HH}}\right.$ not observed, $\left.2 \mathrm{H}, \operatorname{arylH}\right), 6.94(\mathrm{~m}$, $J_{\mathrm{HH}} 4.0 \mathrm{~Hz}, 2 \mathrm{H}$, arylH), $5.82\left(2 \mathrm{x}\right.$ overlapping doublets, ${ }^{2} J_{\mathrm{HH}} 12.0 \mathrm{~Hz}, 2 \mathrm{H}$, endo-C $\left.H_{2}\right), 5.48(2 \mathrm{x}$ overlapping doublets, ${ }^{2} J_{\mathrm{HH}} 12.0 \mathrm{~Hz}, 2 \mathrm{H}$, endo-C $\mathrm{CH}_{2}$ ), 5.40 (2x overlapping doublets, ${ }^{2} J_{\mathrm{HH}} 14.0 \mathrm{~Hz}, 2 \mathrm{H}$, endo- $\left.\mathrm{CH}_{2}\right), 4.50$ (2x overlapping doublets, ${ }^{2} \mathrm{~J}_{\mathrm{HH}} 12.0 \mathrm{~Hz}, 2 \mathrm{H}$, endo- $\mathrm{CH}_{2}$ ), 3.45 (2x overlapping doublets, ${ }^{2} J_{\mathrm{HH}} 12.0 \mathrm{~Hz}, 2 \mathrm{H}$, exo- $\mathrm{CH}_{2}$ ), 3.38 (4x overlapping doublets, ${ }^{2} J_{\mathrm{HH}}$ obscurred, $4 \mathrm{H}$, exo-C $\mathrm{CH}_{2}$ ), 
3.23 (2x overlapping doublets, ${ }^{2} J_{\mathrm{HH}} 12.0 \mathrm{~Hz}, 2 \mathrm{H}$, exo-CH ), 1.97 (s, 24H, MeCN), 1.96 (s (partially obscurred by $\mathrm{CD}_{3} \mathrm{CN}, 12 \mathrm{H}, \mathrm{MeCN}$ ), $1.26-1.24$ (overlapping s, $\left.54 \mathrm{H}, \mathrm{C}\left(\mathrm{CH}_{3}\right)_{3}\right), 1.21-1.20(2 \mathrm{x} \mathrm{s}$, $\left.18 \mathrm{H}, \mathrm{C}\left(\mathrm{CH}_{3}\right)_{3}\right), \mathrm{OH}$ not observed.

\section{Synthesis of $\left[t-\mathrm{BuNH}_{3}\right]\left\{[\mathrm{V}(p \text {-tolylN })]_{2} \mathrm{~L}^{8} \mathrm{H}\right\} \cdot 3 \frac{1}{2} \mathrm{MeCN}\left(\mathbf{6} \cdot 3 \frac{1}{2} \mathrm{MeCN}\right)$}

$\left[\mathrm{V}(t-\mathrm{BuN})(\mathrm{O} t-\mathrm{Bu})_{3}\right](0.5 \mathrm{~g}, 1.46 \mathrm{mmol})$ and $\left[\mathrm{V}(p-\right.$ tolylN $\left.)(\mathrm{O} t-\mathrm{Bu})_{3}\right](0.55 \mathrm{~g}, 1.46 \mathrm{mmol})$ in toluene $(30$ $\left.\mathrm{cm}^{3}\right)$ were stirred at ambient temperature for $3 \mathrm{~h} . \mathrm{L}^{8} \mathrm{H}_{8}(1.90 \mathrm{~g}, 1.46 \mathrm{mmol})$ was added, and the system was refluxed for $6 \mathrm{~h}$, after which volatiles were removed in-vacuo and the residue was extracted into warm $\mathrm{MeCN}\left(30 \mathrm{~cm}^{3}\right)$. Prolonged standing at ambient temperature afforded orange/brown plates of $\mathbf{6}$, Yield: $0.71 \mathrm{~g}, 26 \%$. Further cooling to $-20{ }^{\circ} \mathrm{C}$ afforded further crops of 6 along with a highly solvent dependant brown solid. elemental analysis calculated for $6 \cdot 3 \frac{1}{2} \mathrm{CH}_{3} \mathrm{CN}, \mathrm{C}_{113} \mathrm{H}_{141.5} \mathrm{~N}_{6.5} \mathrm{~V}_{2} \mathrm{O}_{8}$ : C 74.5, H 7.8, N $5.0 \%$; found: C 73.7, H 7.4, N $4.5 \%$; IR (nujol mull, $\mathrm{KBr}, \mathrm{cm}^{-1}$ ): 2078w, 1594w, 1419w, $1402 \mathrm{w}, 1302 \mathrm{w}, 1261 \mathrm{~s}, 1200 \mathrm{~m}, 1097 \mathrm{bs}, 1022 \mathrm{~s}, 912 \mathrm{w}, 872 \mathrm{w}, 832 \mathrm{~m}, 795 \mathrm{~s}, 726 \mathrm{w}, 705 \mathrm{w}, 669 \mathrm{w}, 653 \mathrm{w}$ 642w, 613w, 574w, 558w, 532w, 450w. ${ }^{1} \mathrm{H}$ NMR $\left(\mathrm{CDCl}_{3}\right.$, sample dried in-vacuo for $\left.1 \mathrm{~h}\right) \delta: 8.35$ (br s, $t \mathrm{BuN} H_{3}$ ), 7.30 - 6.92 (overlapping m, 24H, aryl $H$ ), $4.80\left(\mathrm{~d},{ }^{2} J_{\mathrm{HH}} 12.0 \mathrm{~Hz}, 2 \mathrm{H}\right.$, endo- $\left.\mathrm{CH}_{2}\right), 4.61$ (bm, $2 \mathrm{H}$, endo- $\left.\mathrm{CH}_{2}\right), 4.35\left(\mathrm{bm}, 2 \mathrm{H}\right.$, endo- $\left.\mathrm{CH}_{2}\right), 4.22\left(\mathrm{~d},{ }^{2} J_{\mathrm{HH}} 12.0 \mathrm{~Hz}, 2 \mathrm{H}\right.$, endo- $\left.\mathrm{CH}_{2}\right), 3.39\left(\mathrm{~d},{ }^{2} J_{\mathrm{HH}} 11.6\right.$ $\mathrm{Hz}, 2 \mathrm{H}$, exo- $\left.\mathrm{CH}_{2}\right), 3.29\left(\mathrm{bm}, 2 \mathrm{H}\right.$, exo- $\left.\mathrm{CH}_{2}\right), 3.12\left(\mathrm{~d},{ }^{2} J_{\mathrm{HH}} 12.0 \mathrm{~Hz}, 2 \mathrm{H}\right.$, exo- $\left.\mathrm{CH}_{2}\right), 3.01(\mathrm{bm}, 2 \mathrm{H}$, exo$\left.\mathrm{CH}_{2}\right), 2.35$ (s, 6H, $\left.\mathrm{CH}_{3} \mathrm{C}_{6} \mathrm{H}_{4}\right), 2.00$ (s, 6H, MeCN), 1.48, 1.34, 1.24, 1.14 (4x s, 72H, $\left.\mathrm{C}\left(\mathrm{CH}_{3}\right)_{3}\right), \mathrm{OH}$ not observed.

\section{Polymer Characterization}

The melt transition temperatures $\left(T_{\mathrm{m}}\right)$ of the polyethylene (PE) and ethylene/propylene copolymer (EPR) were determined by differential scanning calorimetry (DSC) with a Shimadzu DSC-60 instrument. The polymer samples were heated at $50{ }^{\circ} \mathrm{C} / \mathrm{min}$ from $20{ }^{\circ} \mathrm{C}$ to $200{ }^{\circ} \mathrm{C}$, held at $200{ }^{\circ} \mathrm{C}$ for 5 
min, and cooled to $0{ }^{\circ} \mathrm{C}$ at $20{ }^{\circ} \mathrm{C} / \mathrm{min}$. The samples were held at this temperature for $5 \mathrm{~min}$, and then reheated to $200{ }^{\circ} \mathrm{C}$ at $10{ }^{\circ} \mathrm{C} / \mathrm{min}$. The reported $T_{\mathrm{m}}$ was determined from the second heating scan unless otherwise noted.

Molecular weights $\left(M_{\mathrm{w}}\right.$ and $M_{\mathrm{n}}$ ) and polymer disparity index (PDI) of PE and EPR were determined using a Waters GPC2000 gel permeation chromatograph equipped with four TSKgel columns (two sets of TSKgelGMH 6 - $\mathrm{HT}$ and two sets of $\mathrm{TSKgelGMH}_{6}-\mathrm{HTL}$ ) at $140{ }^{\circ} \mathrm{C}$ using polystyrene calibration. $o$ Dichlorobenzene (ODCB) was used as the solvent.

The propylene content of the EPR was measured by IR analysis using a JASCO FT-IR.

\section{Polymerization Procedure}

Polymerization reactions were performed in a parallel pressure reactor (Argonaut Endeavor ${ }^{\circledR}$ Catalyst Screening System) containing 8 reaction vessels $(15 \mathrm{~mL})$ each equipped with a mechanical stirrer and monomer feed lines. At first, a toluene solution (and a toluene solution of ETA as necessary) was injected into each vessel. For ethylene polymerization, the solution was heated to the polymerization temperature $\left(T_{\mathrm{p}}\right)$ and thermally equilibrated, and the nitrogen atmosphere was replaced with ethylene and the solution was saturated with ethylene at the polymerization pressure. For ethylene/propylene copolymerization, the nitrogen atmosphere was replaced with propylene and the reaction vessels were pressurized with propylene $\left(0.4 \mathrm{MPa}\right.$ at $\left.25^{\circ} \mathrm{C}\right)$, and the solution was heated to the $T_{\mathrm{p}}$ and thermally equilibrated, then ethylene was introduced into the reactor up to the polymerization pressure. In all cases the polymerization was started by addition of a toluene solution of alkyl aluminum or alkyl aluminum chloride followed by addition of a toluene solution of the vanadium complex $(0.50 \mathrm{~mL}$ toluene solution of complex followed by $0.25 \mathrm{~mL}$ toluene wash). The total volume of the reaction mixture was $5 \mathrm{~mL}$ for all polymerizations. The pressure was kept constant by feeding ethylene on demand. After the reaction, the polymerization was stopped by addition of 
excess isobutyl alcohol. The resulting mixture was added to acidified methanol ( $45 \mathrm{ml}$ containing 0.5 $\mathrm{ml}$ of concentrated $\mathrm{HCl})$. The polymer was recovered by filtration, washed with methanol $(2 \times 10 \mathrm{ml})$ and dried in a vacuum oven at $80{ }^{\circ} \mathrm{C}$ for $10 \mathrm{~h}$.

\section{Crystallography}

This set of structures were particularly challenging, so we describe here the details of how the various problems were approached. Crystal data were collected on a Bruker SMART 1000 CCD diffractometer using narrow slice $0.3^{\circ} \omega$-scans for 6.31 $\frac{1}{2} \mathrm{MeCN}$, (Bruker APEX 2 for 1.4MeCN, 2.10MeCN, 3. $3 \mathrm{MeCN}, \mathbf{3} \cdot 3 \mathrm{CH}_{2} \mathrm{Cl}_{2}$, and 5. $8 \mathrm{MeCN}$ ). [16] Data for 5.10MeCN, 3.3MeCN, and $\mathbf{3} \cdot 3 \mathrm{CH}_{2} \mathrm{Cl}_{2}$ were collected at Daresbury Laboratory SRS Station 9.8 using silicon 111 monochromated X-radiation due to small crystal size or weak diffraction [17]. Data for $4 \cdot \mathrm{Et}_{2} \mathrm{O}$ was collected on a Rigaku AFC12 Saturn 724+ Kappa CCD diffractometer using a rotating anode source. [18] Data were corrected for Lp effects and for absorption, based on repeated and symmetry equivalent reflections [16, 17], and solved by direct methods $[19,20]$. Structures were refined by full matrix least squares on $F^{2}[19,20]$. H atoms were included in a riding model except for $\mathrm{H}(5)$ in $1.4 \mathrm{MeCN}, \mathrm{H}(2)$ and $\mathrm{H}(6)$ in $5.8 \mathrm{MeCN}$, and $\mathrm{H}(7)$ in 6.31/2 MeCN for which coordinates were freely refined. Hydrogen atom $U_{\text {iso }}$ values were constrained to be $120 \%$ of that of the carrier atom except for methyl, ammonium, and hydroxyl-H (150\%). Several structures exhibited two-fold disorder in, tert-butyl groups and/or solvent molecules where restraints were applied to geometry and anisotropic displacement parameters. Some solvent molecules were diffuse and refined at half weight so numbers of solvent molecules of crystallisation should be regarded as approximate. Structures $3 \cdot 3 \mathrm{MeCN}$ and $\mathbf{3} \cdot 3 \mathrm{CH}_{2} \mathrm{Cl}_{2}$ are isomorphous and are two-component twins related via a $180^{\circ}$ rotation about reciprocal axis $\left[\begin{array}{lll}0 & 1 & 0\end{array}\right]$. The major component was 56.80(16) \% in the case of the former. Structure $3 \cdot 3 \mathrm{MeCN}$ was best treated using the diffraction intensities from 
both twin components, while for $3 \cdot 3 \mathrm{CH}_{2} \mathrm{Cl}_{2}$ approximately detwinned diffraction data were used. The badly disordered third $\mathrm{CH}_{2} \mathrm{Cl}_{2}$ in $\mathbf{3} \cdot 3 \mathrm{CH}_{2} \mathrm{Cl}_{2}$, three acetonitriles in $\mathbf{2} \cdot 10 \mathrm{MeCN}$, and the $\mathrm{Et}_{2} \mathrm{O}$ in $\mathbf{4} \cdot \mathrm{Et}_{2} \mathrm{O}$ were modelled as regions of diffuse electron density by the Platon Squeeze procedure. [21] Twinning is suspected in structures $2 \cdot 10 \mathrm{MeCN}$ and $\mathbf{4} \cdot \mathrm{Et}_{2} \mathrm{O}$, and $\mathbf{5} \cdot 8 \mathrm{MeCN}$ but no satisfactory twin model could be developed. Further details are provided in Table 6. CCDC 895364 - 895369 and 1017370-1017371 contain the supplementary crystallographic data for this paper. These data can be obtained free of charge from The Cambridge Crystallographic Data Centre via www.ccdc.cam.ac.uk/data_request/cif.

\section{Acknowledgements}

The EPSRC and STFC are thanked for financial support (including an Overseas Travel grant to CR) and the award of beamtime at Daresbury Laboratory (Station 9.8). Drs Simon J. Coles, John E. Warren and Pierre J. Rizkallah are thanked for technical support at Daresbury Laboratory. The EPSRC Mass Spectrometry Service (Swansea, UK) and the EPSRC National X-ray Crystallographic Service (Southampton) are thanked for data collection.

Supporting Information Available: X-ray crystallographic files CIF format for the structure determinations of compound $\mathbf{1}-\mathbf{6}$. 
Table 6. Crystallographic data for complex $1 \cdot 4 \mathrm{MeCN}, \mathbf{2} \cdot 10 \mathrm{MeCN}, \mathbf{3} \cdot 3 \mathrm{MeCN}$ and $\mathbf{3} \cdot 3 \mathrm{CH}_{2} \mathrm{Cl}_{2}$

\begin{tabular}{|c|c|c|c|c|}
\hline Compound & $\mathbf{1} \cdot 4\left(\mathrm{CH}_{3} \mathrm{CN}\right)$ & $\mathbf{2} \cdot 10\left(\mathrm{CH}_{3} \mathrm{CN}\right)$ & 3.3 $\left(\mathrm{CH}_{3} \mathrm{CN}\right)$ & 3.3 $\left(\mathrm{CH}_{2} \mathrm{Cl}_{2}\right)$ \\
\hline Formula & $\mathrm{C}_{98} \mathrm{H}_{120} \mathrm{~V}_{2} \mathrm{~N}_{5} \mathrm{NaO}_{10} \cdot 4 \mathrm{CH}_{3} \mathrm{CN}$ & $\mathrm{C}_{212} \mathrm{H}_{262} \mathrm{~V}_{8} \mathrm{~N}_{18} \mathrm{Na}_{8} \mathrm{O}_{32} \cdot 10 \mathrm{CH}_{3} \mathrm{CN}$ & $\mathrm{C}_{88} \mathrm{H}_{104} \mathrm{~V}_{4} \mathrm{O}_{14} \cdot 3 \mathrm{CH}_{3} \mathrm{CN}$ & $\mathrm{C}_{88} \mathrm{H}_{104} \mathrm{~V}_{4} \mathrm{O}_{14} \cdot 3 \mathrm{CH}_{2} \mathrm{Cl}_{2}$ \\
\hline $\begin{array}{l}\text { Formula weight } \\
\text { Crystal system }\end{array}$ & $\begin{array}{l}1817.08 \\
\text { monoclinic }\end{array}$ & $\begin{array}{l}4576.38 \\
\text { monoclinic }\end{array}$ & $\begin{array}{l}1712.63 \\
\text { triclinic }\end{array}$ & $\begin{array}{l}1844.25 \\
\text { triclinic }\end{array}$ \\
\hline Space group & $P 2_{1} / n$ & $P 2_{1} / n$ & $P \overline{1}$ & $P \overline{1}$ \\
\hline \multicolumn{5}{|l|}{$\begin{array}{l}\text { Unit cell } \\
\text { dimensions }\end{array}$} \\
\hline$a(\AA)$ & $12.4731(7)$ & $20.8729(9)$ & $13.763(6)$ & $13.870(2)$ \\
\hline$b(\AA)$ & $31.3969(17)$ & $21.4271(9)$ & $18.382(8)$ & $18.180(3)$ \\
\hline$c(\AA)$ & $27.8042(15)$ & $30.0519(12)$ & $18.985(8)$ & $18.983(3)$ \\
\hline$\alpha\left({ }^{\circ}\right)$ & 90 & 90 & $74.641(6)$ & $75.296(2)$ \\
\hline$\beta\left(^{\circ}\right)$ & $102.8887(8)$ & $103.6628(18)$ & $86.251(6)$ & $86.178(2)$ \\
\hline$\gamma\left({ }^{\circ}\right)$ & 90 & 90 & $79.451(7)$ & $77.749(2)$ \\
\hline$V\left(\AA^{3}\right)$ & $10614.2(10)$ & 13060.2(9) & $4553(3)$ & $4524.0(13)$ \\
\hline$Z$ & 4 & 2 & 2 & 2 \\
\hline Temperature (K) & $150(2)$ & $150(2)$ & $150(2)$ & $150(2)$ \\
\hline Wavelength $(\AA)$ & 0.71073 & 0.6939 & 0.6884 & 0.6911 \\
\hline $\begin{array}{l}\text { Calculated } \\
\text { density } \\
\left(\mathrm{g} . \mathrm{cm}^{-3}\right)\end{array}$ & 1.137 & 1.164 & 1.249 & 1.354 \\
\hline $\begin{array}{l}\text { Absorption } \\
\text { coefficient } \\
\left(\mathrm{mm}^{-1}\right)\end{array}$ & 0.238 & 0.352 & 0.460 & 0.638 \\
\hline $\begin{array}{l}\text { Transmission } \\
\text { factors } \\
(\min . / \max .)\end{array}$ & 0.900 and 0.939 & 0.881 and 0.924 & 0.918 and 0.991 & 0.852 and 0.975 \\
\hline $\begin{array}{l}\text { Crystal size } \\
\left(\mathrm{mm}^{3}\right)\end{array}$ & $0.45 \times 0.28 \times 0.27$ & $0.37 \times 0.30 \times 0.23$ & $0.19 \times 0.07 \times 0.02$ & $0.26 \times 0.05 \times 0.04$ \\
\hline$\theta(\max )\left(^{\circ}\right)$ & 27.2 & 24.0 & 24.0 & 26.7 \\
\hline $\begin{array}{l}\text { Reflections } \\
\text { measured }\end{array}$ & 99178 & 110060 & 57516 & 71017 \\
\hline $\begin{array}{l}\text { Unique } \\
\text { reflections }\end{array}$ & 23497 & 22011 & 15616 & 20773 \\
\hline$R_{\mathrm{int}}$ & 0.0832 & 0.0973 & 0.1565 & 0.0921 \\
\hline $\begin{array}{l}\text { Reflections with } \\
F^{2}>2 \sigma\left(F^{2}\right)\end{array}$ & 14780 & 14349 & 8595 & 15274 \\
\hline $\begin{array}{l}\text { Number of } \\
\text { parameters }\end{array}$ & 1320 & 1512 & 1114 & 1058 \\
\hline$R_{1}\left[F^{2}>2 \sigma\left(F^{2}\right)\right]$ & 0.0609 & 0.1156 & 0.0829 & 0.0932 \\
\hline$w R_{2}$ (all data) & 0.1905 & 0.2870 & 0.2291 & 0.2706 \\
\hline GOOF, $S$ & 1.038 & 1.315 & 0.970 & 1.066 \\
\hline
\end{tabular}


Table 6 con't. Crystallographic data for complex $4 \cdot \mathrm{Et}_{2} \mathrm{O}, 5 \cdot 8 \mathrm{MeCN}$ and $6 \cdot 31 / 2 \mathrm{MeCN}$.

\begin{tabular}{|c|c|c|c|}
\hline Compound & 4. $\mathrm{Et}_{2} \mathrm{O}$ & 5.8MeCN & 6.31/2( $\left.\mathrm{CH}_{3} \mathrm{CN}\right)$ \\
\hline Formula & $\mathrm{C}_{112} \mathrm{H}_{160} \mathrm{~V}_{4} \mathrm{O}_{22} \mathrm{Li}_{6} \cdot \mathrm{Et}_{2} \mathrm{O}$ & $\mathrm{C}_{88} \mathrm{H}_{105} \mathrm{~V}_{2} \mathrm{O}_{10} \cdot \mathrm{C}_{8} \mathrm{H}_{12} \mathrm{LiN}_{4} \cdot 8 \mathrm{CH}_{3} \mathrm{CN}$ & $\mathrm{C}_{106} \mathrm{H}_{131} \mathrm{~V}_{2} \mathrm{~N}_{3} \mathrm{O}_{8} \cdot 3 \frac{1}{2} \mathrm{CH}_{3} \mathrm{CN}$ \\
\hline Formula weight & 2175.89 & 1924.18 & 1820.71 \\
\hline Crystal system & monoclinic & triclinic & triclinic \\
\hline Space group & $C 2 / c$ & $P \overline{1}$ & $P \overline{1}$ \\
\hline \multicolumn{4}{|l|}{ Unit cell dimensions } \\
\hline$a(\AA)$ & $33.361(16)$ & $12.519(3)$ & $12.2630(13)$ \\
\hline$b(\AA)$ & $12.011(5)$ & $16.085(3)$ & $16.9231(17)$ \\
\hline$c(\AA)$ & $32.820(14)$ & $29.079(6)$ & $27.809(3)$ \\
\hline$\alpha\left(^{\circ}\right)$ & 90 & $80.780(3)$ & $103.9105(18)$ \\
\hline$\beta\left(^{\circ}\right)$ & $116.34(4)$ & $85.871(3)$ & $100.1796(19)$ \\
\hline$\gamma\left({ }^{\circ}\right)$ & 90 & $73.333(3)$ & $93.2503(18)$ \\
\hline$V\left(\AA^{3}\right)$ & $11786(10)$ & $5535(2)$ & $5484.2(10)$ \\
\hline$Z$ & 4 & 2 & 2 \\
\hline Temperature (K) & $100(2)$ & $150(2)$ & $150(2)$ \\
\hline Wavelength $(\AA)$ & 0.71073 & 0.71073 & 0.71073 \\
\hline $\begin{array}{l}\text { Calculated density } \\
\qquad\left({\left.\mathrm{g} . \mathrm{cm}^{-3}\right)}^{-3}\right.\end{array}$ & 1.226 & 1.155 & 1.103 \\
\hline $\begin{array}{l}\text { Absorption coefficient } \\
\qquad\left(\mathrm{mm}^{-1}\right)\end{array}$ & 0.373 & 0.229 & 0.225 \\
\hline $\begin{array}{l}\text { Transmission factors } \\
\text { (min./max.) }\end{array}$ & 0.964 and 0.987 & 0.849 and 0.966 & 0.869 and 0.991 \\
\hline Crystal size $\left(\mathrm{mm}^{3}\right)$ & $0.10 \times 0.07 \times 0.04$ & $0.74 \times 0.31 \times 0.15$ & $0.64 \times 0.11 \times 0.04$ \\
\hline$\theta(\max )\left(^{\circ}\right)$ & 27.5 & 28.5 & 25.0 \\
\hline Reflections measured & 47065 & 74023 & 36900 \\
\hline Unique reflections & 13465 & 27412 & 18857 \\
\hline$R_{\text {int }}$ & 0.0553 & 0.1004 & 0.0834 \\
\hline $\begin{array}{c}\text { Reflections with } F^{2}> \\
2 \sigma\left(F^{2}\right)\end{array}$ & 9918 & 15246 & 8410 \\
\hline Number of parameters & 782 & 1392 & 1201 \\
\hline$R_{1}\left[F^{2}>2 \sigma\left(F^{2}\right)\right]$ & 0.0872 & 0.0860 & 0.0734 \\
\hline$w R_{2}$ (all data) & 0.2686 & 0.2288 & 0.2441 \\
\hline GOOF, $S$ & $\begin{array}{c}1.051 \\
0.836\end{array}$ & 1.042 & 0.979 \\
\hline S & 0.836 and -0.896 & 1.143 and -0.720 & 0.680 and -0.367 \\
\hline
\end{tabular}


Largest difference peak and hole $\left(\mathrm{e} \AA^{-3}\right)$ 


\section{References}

1. D. M. Homden and C. Redshaw, Chem. Rev., 2008, 108, 5086.

2. L. Giannini, A. Caselli, E. Solari, C. Floriani, A. Chiesi-Villa, C. Rizzoli, N. Re, A. Sgamellotti, J. Am. Chem. Soc. 1997, 119, 9198.

3. a) C. Redshaw, Coord. Chem. Rev., 2003, 244, 45. (b) The Chemistry of Metal Phenolates. Ed. Jacob Zabicky, Publisher Wiley, Y. Li, K.-Q. Zhao, C. Redshaw, A. Y. Nuñez, B. A. M. Ortega, S. Memon and T. A. Hanna, 2014, ISBN:978-0-470-97358-5.

4. For recent examples, see a) R.D. McIntosh, S.M. Taylor, S. Sanz, C.M. Beavers, S.J. Teat, E.K. Brechin and S.J. Dalgarno, Dalton Trans. 2011, 40, 12265 and references therein.

5. a) S. Singh and H. W. Roesky, Dalton Trans., 2007, 1360. b) M. P. Weberski, Jr, C. Chen, M. Delferro, and T. J. Marks, Chem. Eur. J. 2012 18, 10715. c) M. Delferro, and T. J. Marks, Chem. Rev. 2011, 111 (3), 2450-2485.

6. (a) E. Hoppe, C. Limberg and B. Ziemer, Inorg. Chem., 2006, 45, 8308. (b) E. Hoppe, C. Limberg, B. Ziemer and C. Mügge, J. Mol. Cat A: Chem., 2006, 251, 34. (c) C. Limberg, Eur. J. Inorg. Chem., 2007, 3303.

7. (a) V.C. Gibson, C. Redshaw and M.R.J. Elsegood, J. Chem. Soc., Dalton Trans., 2001, 767. (b) C. Redshaw, M. A. Rowan, L. Warford, D. M. Homden, A. Arbaoui, M. R. J. Elsegood, S. H. Dale, T. Yamato, C. P. Casas and S. Matsui, Chem. Eur. J., 2007, 13, 1090. (c) L. Clowes, C. Redshaw and D.L. Hughes, Inorg. Chem. 2011, 50, 7838. (d) C. Redshaw, L. Clowes, D.L. Hughes, M.R.J. Elsegood and T. Yamato, Organometallics 2011, 30, 5620.

8. C. Redshaw, D. Homden, D. L. Hughes, J. A. Wright and M. R. J. Elsegood, Dalton Trans. 2009, 1231-1242.

9. A. Arbaoui, C. Redshaw, M. R.J. Elsegood, V. E. Wright, A. Yoshizawa and T. Yamato, Chem. Asian J. 2010 5, 621.

10. C. Redshaw, M.J. Walton, K. Michiue, Y. Chao, A. Walton, P. Elo, V. Sumerin, C. Jiang and M.R.J. Elsegood, manuscript in preparation.

11. M. Bochmann, G. Wilkinson, G. B. Young, M. B. Hursthouse, K. M. A. Malik, J. Chem. Soc., Dalton Trans. 1980, 1863.

12. (a) G.E. Hofmeister, F.E. Hahn and S.F. Pedersen, J. Am. Chem. Soc., 1989, 111, 2318. (b) G.E. Hofmeister, E. Alvarado, J.A. Leary, D.I. Yoon and S.F. Pedersen, J. Am. Chem. Soc., 1990, 112, 8843. 
13. A. Arduini, A. Casnati in Macrocycle Synthesis (Ed.: D. Parker), Oxford University Press, 1996, chap. 7.

14. D. D. Devore, J. D. Lichtenhan, F. Takusagawa and E. A. Maatta, J. Am. Chem. Soc., 1987, 109, 7408 .

15. The problems associated with calixarene microanalysis are well documented, for example, C. Redshaw, D. Homden, D.L. Hughes, J.A. Wright and M.R.J. Elsegood, Dalton Trans, 2009, 1231.

16. SMART (2001), SAINT (2001 \& 2008\&12), and APEX 2 (2008\&12) software for CCD diffractometers. Bruker AXS Inc., Madison, USA.

17. (a) W. Clegg, M. R. J. Elsegood, S. J. Teat, C. Redshaw and V. C. Gibson, J. Chem. Soc., Dalton Trans., 1998, 3037.

18. Rigaku Crystal Clear-SM Expert 3.1 b24 (2012) software for Diffractometers, Rigaku Corp.

19. G.M. Sheldrick, SHELXTL user manual, version 6.10. Bruker AXS Inc., Madison, WI, USA, (2000).

20. G.M. Sheldrick, (2008), Acta Crystallogr. A64, 112-122.

21. A.L. Spek, (1990), Acta Crystallogr. A46, C34. 